\title{
O novo Código Civil brasileiro e a reorganização de empresas
}

\author{
Augusto Jaeger Junior
}

SUMÁRIO

Introdução

Parte 1. O novo Código Civil brasileiro
A. Unificação das obrigações civis e comerciais
B. Direito da empresa no novo Código

Parte 2. Concentrações e desconcentrações empresariais
A. Fenômeno concentracionista e concorrência
B. Formas e fases de compenetração

Considerações Finais

Referências Bibliográficas 


\section{INTRODUÇÃO}

O ptesente trabalho monográfico versará sobre o novo Código Civil brasileiro e a nova orientação quanto ao fenômeno da reorganização de empresas sediadas em território nacional. Trata-se este documento, que em janeito último foi consagrado com a sanção presidencial, de um antigo anseio da comunidade jurídica nacional, tendo tramitado no Congresso Nacional por longos 26 anos, em cujo momento recebeu inúmeros aprimoramentos.

O estudo abrange tema mais sujeito ao amplo campo do direito privado, envolvendo questões referidas a duas de suas principais ramificações, a do direito civil e a do direito comercial, sendo que este último vem referido hodiernamente como direito empresarial. Vale de imediato teferir que, em sede de obrigações, ambos os ramos fotam unificados.

A escolha do tema é reflexo da sugestão ofertada por uma das professoras responsáveis pela discipina Teoria dos Contratos, do Curso de Pós-graduação em Direito da Universidade Federal do Rio Grande do Sul, Dra. Cláudia Lima Marques.

A idéia que será apresentada parte de uma referência aos estudos precursores do jurista Augusto Teixeira de Freitas quanto à unificação das obrigações em um único documento de direito privado e conduz à conclusão que junto com esta, outras questões e o próprio direito empresarial foram trazidos para dentro da esfera civil, especiaimente aqui no que diz respeito a um regramento getal da transformação, da incorporação e da fusão e cisão das sociedades. Ocorre que, além da unificação das obrigações, assuntos outros de direito comercial, como a disciplina da reorganização de empresas, anteriormente abordadas pela lei própria das sociedades de capital, agora em regra generalíssima foram trazidos para dentro do documento que disciplina o ordenamen to civil.

Para tanto, o trabalho será apresentado em duas grandes partes. A primeira abordará a questão central do surginento do novo ordenamento civil brasileiro. Esta primeira parte é subdividida em duas outras. Uma delas retratará a opção do legislador pela unificação das obrigações civis e comerciais num mesmo documento com características de um Código. A segunda sub-parte da primeira parte investigará a introdução do direito da empresa, propriamente dito, neste novo Código.

Na seqüência, para o estabelecimento de um elo de ligação entre as duas partes do trabalho, já tendo especialmente estudado o momento de surgimento de uma base nova para o ordenamento civil e a introdução nesta de um ramo do direito que nunca havia estado em sua esfera de influência, é utilizada uma de suas particularidades, qual seja a matéria constada do capítulo que disciplinará o movimento concentracionista de empresas. Assim, a segunda parte tratará especificamente da concentração e desconcentração empresariais. Esta segunda grande parte igualmente se apresenta subdividida em outras duas. Uma delas fará uma análise pontual do fenômeno concentracionista e do incremento concorrencial que de tal prática decorre. Por fim, a última sub-parte evidenciará quais são as formas e fases de compenetração empresarial admitidas em dìreito brasileiro e mais utilizadas pelas empresas. 
Ainda nessa introdução cabe dizer que o propósito da realização deste estudo no recorte em que será apresentado se justifica no fato de ser este o oportuno momento do surgimento de um novo Código Civil brasileiro que, ao positivar parcialmente sua idéia, ressaltou novamente a importância dos estudos de Augusto Teixeira de Freitas, brasileiro ilustre que em 1854 já havia insistido na unificação do direito obrigacional.

Igualmente, o incremento das relações envolvendo as empresas, do comércio em si e a utilização de práticas concorrenciais colusórias por elas, geralmente decorrentes de conjugadas práticas concentracionistas, a cada dia mais agressivas e corriqueiras, aumentou a possibilidade de comportamentos lesivos ao direito, o que enseja cada vez mais estudos sobre o tema, como este que se apresentará a seguir.

\section{PARTE 1}

\section{O NOVO CÓDIGO CIVIL BRASILEIRO}

A primeira parte deste estudo é voltada para o surgimento do novo ordenamento basilar civil do Brasil, retratando, em especial, as tentativas históricas de grandes personalidades e legisladores no que tange à unificação das obrigaçōes civis e comerciais num documento único, agora realidade. Este fato faz com que mereça ser tratado rangencialmente um outro tema, qual seja a manutenção de uma cerra autonomia por parte do direito comercial, mesmo didática e científica, perante o direito civil. Por fim, será investigada a introdução do direito da empresa neste novo Código, sistematização inovadora em direito brasileiro, cujos artigos vêm diretamente dispostos após o direito das obrigações.

\section{A. Unificação das obrigações civis e comerciais}

Para um melhor tratamento do tema da unificação das obrigações civis e comerciais será utilizado um critério histórico-cronológico, pois este permite apresentar a evolução do pensamento jurídico brasileiro até uma definitiva junção dos ramos em um único documento. Ainda, serão trazidas as posições de renomados juristas que apóiam ou não apóiam a inclusão das obrigações comerciais em um documento civil.

A idéia da unificação das obrigações não é recente. Segundo Munir KARAM a aspiração de condensar as normas juridicas em um único corpo de direito esteve presente desde as mais antigas civilizações ${ }^{1}$. Contudo, uma estrita análise de parte da histótia jurídica brasileira é mais apropriada, até mesmo devido ao espaço aqui destinado para tal tema.

${ }^{1}$ KARAM, Munir. Teixeira de Freitas e o processo de codificação do Direito Civil Brasileiro, p. 95. 
Assim, em 1808 o Brasil abriu os portos para as rações amigas, através da Carta Régia, decisão esta que veio diretamentc em proveito do incremento comercial da então colônia com outras nações. Este fato, se isoladamente analisado, em nada diz tespeito à unificação das obrigações. Mas a verdade é que o incremento comercial experimentado pelo país fez ser necessátia una legislação cometcial. E esta, como é sabido, terminou precedendo a uma legislação civil.

Posteriormente à abertura dos portos, com o advento da Independência, em 1822, passaram a vigorar em território nacional as Ordenações Portuguesas. A título de exemplo, observa-se que somente em 1830 é que um Código Penal emergiu, não desconhecendo o surgimento da primeira Constituição Federal de 1824.

Na seqüência, em 1850 surgiu o Código Comercial brasileiro, ordenamento que tecebeu forte influência do Código Francês de 1807. Esta Lei ficou em discussão na Câmara dos Deputados por 16 anos, até ter sido promulgada pelo impetador constitucional Dom Pedro II. Atualmente é o diploma mais antigo em vigor no Brasil.

Como será oportunamente visto, do texto original em vigor restava já muito pouco, e menos ainda agora, com a unificação em um Código Civil das obrigações civis e comerciais. Por tal, no Código Comercial a única parte ainda a vigorar futuramente será a relacionada com o direito marítimo.

Como o Código Comercial veio antes que um ordenamento civil, foi tido como natural que incluíta muitas disciplinas de matérias que não constavam da desordenada legislação civil de então ${ }^{2}$. Assim, definitivamente tendo ocorrido tal prática, afirmado foi na época que o referido documento era o quc tinha invadido a esfera do direito civil; e não vice-versa, como arualmente se processou.

En que pese surgido em 1850, Luiz Antonio Guerra da SILVA, em artigo que trata da contemporaneidade do Código acima referido, observa sua presteza, ainda que a dinâmica dos fatos e as novas relações mercantis sinalizem com a globalização da economia. Para o autor, atualmente as críticas que podem ser feitas se referem à defasada redação imperial cmpregada no regramento dos institutos e no fato de o crescimento econômico ter exigido novas formas de contratação, determinando o surgimento de outros institutos específicos ${ }^{3}$. Por tal, o Brasil necessitava mesmo se apresentar receptivo à criação desses novos institutos e atualizar a legislação comercial, base dos institutos, frente às exigências econômicas, sem, contudo, abandonar as raizes e a história do seu ordenarnento jutídico.

O surgimento de um Código que regulasse o direito civil não tinha a mesma sorte ${ }^{4}$.

2 MARTINS, Fran. Contratos e obrigaçôes comerciais, p. 8.

${ }^{3}$ SILVA, Luiz Antonio Guerra da. Contemporaneidade do Código Comercial imperial: breves considerações, p. 121-122.

${ }^{4}$ KARAM, M. Op.cit., p. 97. 
Como será visto, vários problemas attasaram o surgimento de uma lei com tal característica, mas jamais pode ser dito que isto ocorreu por falta de estudos, propostas e tentativas legislativas.

Neste sentido, em 1854 o jurista brasileiro Augusto Teixeira de Freitas, ao propor um Código Civil para o Brasil, já insistia fortemente na unificação do direiro obrigacional, cujo entendimento seria mais consentâneo para o ordenamento jurídico brasileiro. Afirmava o renomado estudioso que o direito civil e comercial não eram distintos. A divisão era uma falsificação e uma frivolidade, pois a separação escondia o rompimento da igualdade entre as pessoas (dava só ao comerciante o direito de falir, por exemplo).

Sobre a personalidade marcante de Teixeira de Freitas, é possível ser dito que ele pensava em descompasso com o seu tempo ${ }^{5}$. Vale ainda lembrar que se tratava de um perfeccionista $^{6}$. Segundo depoimentos colhidos, em sua vida Teixeira de Freitas produziu uma obra perfeita. Também como pessoa humana foi uma referência: certa feita se recusou a acolher as normas escravistas em seu documento, pois acreditava que logo fossem cair, a morte civil e a restrição aos direitos civis nos nacionais?

E não somente em seu país seu trabalho foi destacado, mas sua obra setviu como um ponto de convergência na legislaçăo civil entre os povos da América ${ }^{8}$. $O$ ordenamento civil da Argentina, por exemplo, com o esforço de Vélez Sarsfield", tomou 1.200 artigos do seu Esboço. Igual influência foi reproduzida no Uruguai, com o estudo de Tristán Narvaja. Já no Paraguai foi adotado o Código Argentino que, como visto acima, recebeu influência de Teixeira de Freitas ${ }^{10}$.

Além-mar, pensamento semelhante às suas idéias Vivante, na Itália, só foi ter cinqüenta anos depois ${ }^{11}$, quando também se opunha a um Código Comercial separado do Civil.

Enfim, vale dizer, sobretudo, que sua obra deu início à codificação do direito civil, cujo projeto datou de 1857. Em que pese os relevantes estudos desencadeados, ogoverno federal não foi receptivo a essas novas idéias e o trabalho foi interrompido ainda incomplero.

sIdem, p. 97.

"Idem, p. 100.

${ }^{7}$ Idem, ibidem.

${ }^{8}$ DEL OLMO, Florisbal de Souza. Augusto Teixeira de Freitas: o protojurista do Mercosul, p. 239 e KARAM, M. Op.cit., p. 109.

${ }^{9}$ DEL OLMO, F. de S. Op.cit., p. 240.

${ }^{10}$ KARAM, M. Op.cit., p. 107.

${ }^{11}$ BRANCO, Gerson Luiz Carlos; COSTA e SILVA, Regina Margarida. A vida de Teixeira de Freiras e Elementos Cenrrais de seu Pensamento, p. 30. 
Para nova empreitada legislativa, concluída en 1865 , fora novamente convidado Teixeira de Freitas, tendo se fixado em classificar as matérias e unificar o direito privado. $\mathrm{O}$ Esboço final desta compilação reuniu cinco milheiros de artigos.

Posteriormente a este esforço promovido por Teixeira de Freitas, Inglês de Souza tentou reformar o Código Comercial em 1912, o que não surtiu efeito.

Então em 1916 o ordenamento jurídico brasileito recebeu a aprovação do Código Civil ${ }^{12}$, após longa e tumultuada tramitação ${ }^{13}$, especialmente devido à contestação veemente de Ruy Barbosa, que costumava se referir a ele como um produto do século passado, já que oriundo de elaboração iniciada em 1896.

Uma manifestação sobre o Código Civil que se faz necessária para o seguimento deste trabalho, é que ele não consagtou esta idéia de unificação das obtigações civis e comerciais em um único documento, o que era a proposta de Teixeira de Freitas. Contudo, para desespero de alguns setores nacionais, regulou instirutos que já constavam do Código Comercial de 1850 , causando enorme confusão jurídica.

A idéia de unificação de matérias de direito privado, neste caso em especial a de obrigações civis e comerciais, já tinha sido aplicada em outros ordenamento pelo mundo afora. Os países que a adotaram podem ser classificados segundo os sisternas de unificação que foram utilizados. Assim, há sistemas radicais e moderados.

Os apreciadores do sistema radical desejam uma unificação total dos direitos e os moderados desej̧am uma modificação tão somente das obrigações. Houvera o Brasil adotado um sistema assim, este scria, como pretendido, o moderado.

Um exemplo do processo de unificação segundo o sistema moderado ocorteu no direito suíço, que tem um Código próprio para o direito das obrigações, fora do direito civil. E us exemplo de unificação segundo o sistema radical se deu no direito italiano, onde o Código Civil de 1942 unificou não só as obrigações, mas o direito privado, acabando com a diferença entre atos civis e comerciais e trabalhistas, mas mantendo normas especiais teferentes à agricultura. Lá, differentemente e mais radical que a idéia original brasileira, o documento também comporta o direito do trabalho.

Este modelo iraliano filiado à teoria da empresa se contrapôs ao sistema francês, adotado em 1850 pelo Brasil e por muitos outros países, tais como Bélgica, Holanda, Itália, Espanha e Portugal.

${ }^{12}$ Sobre a influência do Código Civil alemão de 1896 (BGB) neste documento e em Teixeira de Freitas, entre outros, ver MARQUES, Cláudia Lima. Cem anos de Código Civil Alemão: o BGB de 1896 e o Código Civil Brasileiro de 1916.

${ }^{13}$ KARAM, M. Op.cit., p. 102. 
Mas a grande diferença do documento italiano referido acina com o sistema aprovado pelo Brasil por influência de Bevilacqua e agora de Reale é que aquele não tem uma Parte Geral (uma outra elaboração de Teixeira de Freitas) e os atual e futuro Códigos têm, motivo pelo qual o Projeto, agora sancionado, não se confunde con os documentos italiano nem com o suíço, confusão a qual muitos incorrem, segundo Judith H. MARTINS-COSTA ${ }^{14}$. Cópia deles, portanto, não é, como diz Miguel REALE ${ }^{15}$ na Exposição de Motivos do Projeto apresentada ao Ministro Armando Falcão em 16 de janeiro de $1975^{16}$, ao rebater críticas.

Coincidentemente, no mesmo ano de 1942 a Lei de Introdução ao Código Civil brasileiro também era alterada, em função da Segunda Guerra Mundial, estabelecendo um novo elemento de conexão, o domicílio. Este já havia sido indicado como o elemento mais apropriado por Teixeira de Freitas em sua Proposta ${ }^{17}$. Esta modificação, talvez a principal da nova Lei de Introdução, pode ser entendida como um ajuste histórico, já que deu razão, cem anos após, ao iluminado pensador, alrerando o mecanismo de Pimenta Bueno e Clóvis Bevilacqua positivado em 1916, que esrabelecera a nacionalidade como clemento de conexão para as questões de direito internacional privado.

O surgimento de um Código Civil em 1916 que não contemplou a unificação do direito privado, nem mesmo do ramo das obrigações, não conseguiu, todavia, sepultar a idéia de unificação. Novamente a idéia da unificação das obrigações teve tessurgimento em 1940, com o Projeto do Código de Obrigaçōes e especialmente em 1965 com outro Projeto que chegou a ser enviado ao Congresso Nacional, sendo depois igualmente arquivado.

O Projeto de 1975, na parte da atividade negocial, é a quinta versão elaborada a partir de $1964^{18}$. Este trabalho, fruto de uma Comissão de notáveis Revisora e Elaboradora do Código Civil comandada por Miguel Reale, consolidou e aperfeiçoou o que já estava sendo seguido no Brasil ${ }^{19}$, tetratando uma tradição evolutiva do direito positivo. O trabalho apresentado, especialmente na parte da família, contou com a participação do jurista gaúcho Clóvis Veríssimo do Couto e Silva e, na parte das obrigaçôes, consagrou definitivamente a unificação, retomando a idéia à época já centenária de Teixeita de Freitas.

\footnotetext{
" MARTINS-COSTA, Judith, O direito privado como um 'sistema em construção': as cláusulas gerais no Projeto do Código Civil Brasileiro, nota de rodapé número 61.

15 Citado por MAC-DONALD, Norberto da Costa Caruso. O projeto de Código Civil e o Direito Comercial, p. 142.

" REALE, Miguel. O projeto do novo código civil: situação após a aprovação pelo Senado Federal, p. 43-95.

!7 DEL OLMO, F. de S. Op.cit., p. 244.

is BULGARELII, Waldirio. Tratado de direito empresarial, p. 183.

"MAC-DONALD, N. da C. C. Op.cit., p. 143.
} 
Neste sentido Judith MARTINS-COSTA também assevera a importância do Livro I da Parte Especial, não só em virtude da unificação, mas por concentrar a maior parte das cláusulas gerais em paralelo com as normas marcadas pela estrita casuística ${ }^{20}$.

Sobre a questão da unificação das obrigações, não há o que se confundir com a unificação dos direitos privados, que é outra coisa, e nem era o objetivo da Comissão Revisora e Elaboradora.

Sobretudo, a unificação das obrigações, anteriormente já possível de ser marginalmente visualizada por força dos artigos $121^{21}$ (sobte serem as regras e disposições do Código Civil para os contratos em geral aplicáveis aos contratos comerciais) e 428 do Código Comercial vigente, é um dos grandes avanços do Projeto como contribuição efetiva para a certeza e segutança do direito ${ }^{22}$.

Mas nem todos os doutrinadores brasileiros tinham esta visão da unificação como promissora. Waldirio BULGARELLI, pot exemplo, em algumas situações, coloca em dúvida a unificação, pois há ainda a subsistência de certos atos que podem servir quer aos que não sendo empresátios utilizam ocasionalmente, quer aos empresários que, os estipulando em massa, realizam, por meio deles, uma atividade econômica determinada. A unificação parece, assim para o jurista citado, ameaçada, pois o regime jurídico destes contratos aparentemente não pode ser unitátio ${ }^{23}$.

Uma vez retratada a unificação das obrigações civis e comerciais em um único documento, cabem algumas divagações sobre a manutenção, por parte do direito comercial, de uma certa autonomia, a ser ainda averiguada com o funcionamento do novo sistema.

Numa análise mais restrita, segundo Francesco GALGANO, citado por Norberto da Costa Caruso MAC-DONALD, a unificação importá no desaparecimento daquela que era a parte mais notável do direito conercial, a disciplina das obtigaçōes e dos contratos comerciais ${ }^{24}$. Com efeito, devido à entrada em vigor do Código, do Comercial restará em vigência apenas a parte que trata do comércio marítimo ${ }^{25}$.

\footnotetext{
27 MARTINS COSTA, J. Op.cit, p. 144.

${ }^{21}$ MARTYNS, F. Op.cit, p. 7.

${ }^{22}$ BULGARELLl, W. Op.cit., p. 211.

${ }^{23}$ BULGARELLI, W. Contratos mercantis, p. 46.

${ }^{24}$ MAC-DONALD, N. da C. C. Op.cit., p. 141.

${ }^{25}$ Segundo MAC-DONALD “(...) o art. 2.040 do Projeto revoga expressamente o Código Civil de 1916, a Primeira Parte do Código Comercial de 1850 e toda a legislação civil e mercantil abrangida pelo Código Civil ou com ele incompativel. Se considerarmos que a Terceira Parte do Código Comercial, pertinente às 'quebras', já se encontra derrogada, temos que cotn a entrada em vigor do novo Código restará vigente, alterada por legislação superveniente, apenas a Segunda Parte, que trata do comércio maritimo". Vale referir que o artigo no texto aprovado é o 2.054. Idem, ibidem.
} 
Os estudos sobre a autonomia do direito comercial remetem principalmente a César Vivante, o maior comercialista da Itália dos tempos modernos ${ }^{26}$. Sobre o assunto Vivante proferiu aula em 1892 na Universidade de Bolonha, durante a qual preconizou o fim do direito comercial, condenando sua autonomia e atacando a divisão do direito privado ${ }^{27}$.

Posteriotmente o doutrinador italiano parece ter se retratado perante a comunidade acadèmica comercialista. Com efeiro, Orlando GOMES ${ }^{28}$, Fábio Ulhoa COELHO ${ }^{29}$ e Rubens REQUIÃO falam de uma retratação de Vivante ocortida em 1925, que veio pelo surgimento do liv to $L$ 'autonomie du Droit du Commerce. Segundo REQUIÃO, teve o renomado comercialista o altaneiro espírito de se retratar, confessando o erro doutrinário que cometera em Bolonha com suas previsões sobre a morte do direito comercial ${ }^{30}$.

Ocorre que inegavelmente a obrigação é uma só ${ }^{31}$ e que a dicotomia estabelecia uma desigualdade perante a lei, porque uma categoria, a dos comerciantes, era favorecida com legislação própria que the concedia privilégios e vantagens ${ }^{32}$.

Em verdade, a distinção entre comercial e civil perdeu muito da sua importância em função da unificação do direito das obrigações ${ }^{33}$, aceita quase à unanimidade, e que teve como corolário, em alguns países, a unificação legislativa, como já visto.

Para Waldirio BULLGARELLII pouco ou quase nada sobra para caracterizar o direito comercia $^{34}$, se for observado que a onerosidade já não é mais característica dele, que os imóveis já começam a ser objeto de atividade comercial, que os meios de provas são comuns e que o processo civil é comum. Contudo, o autor prega a manurenção de um direito comercial autônomo em relação ao direito civil, não obstante a unificação das obrigações. Ainda para ele a tendência universal é a unificação das obrigações e a consideração do direito comercial atualmente como direito da empresa. Deve ser mantida a dicotomia do direito privado, reconhecendo-se a autonomia do direito mercantil como diteito do empresário (teoria da empresa), e não mais dos comerciantes. Em função disso, algumas regras específicas devem ser consagradas para a sua organização e atividade, mesmo que inseridas num código único. Por fim, diz ser óbvio que a unificação do direito das obrigações não significa a abolição da vida comercial, com o que conclui seu pensamento sobre o assunto ${ }^{35}$.

\footnotetext{
${ }^{26}$ Igualtnente promotor de célebres estudos sobre a unidade do direito privado em VIVANTE, César. La unidad del Derecho Privado en materia de obligaciones.

${ }^{27}$ REQUIÃO, Rubens. Curso de direito comercial, p. 18.

${ }^{28}$ GOMES, Orlando. Introdução ao direito civil, p. 21.

${ }^{29}$ COELHO, Fábio Ulhoa. Curso de direito comercial, p. 17.

${ }^{39}$ REQUIX̃O, R. Op.cit., p. 1B-20.

MARTINS, F. Op.cit., p. 8.

${ }^{32}$ BRANCO, G. L. C.; COSTA e SILVA, R. M. Op.cit., p. 32.

${ }^{33}$ BULGARELLI, W. Op.cit., p. 41.

${ }^{34}$ Idem, p. 42.

${ }^{35}$ BULGARELLI, W. Tratado de direito empresarial, p. 185.
} 
Já Túlio Ascatelli é partidátio da idéia de que a progressiva expansão da aplicabilidade dos princípios e dos institutos do diteito cometcial tende a torná-lo direito comum ${ }^{36}$, popularizando-se e afastando-se da especialidade (que se teferia à colocação do comerciante em um patamar especial).

Naquele sentido BULGARELLI é seguido por Fran MARTINS ${ }^{37}$. E o próprio REALE fala em integração das relações obrigacionais sem perda do sentido unitário de suas naturais distinções.

Seguindo a dourrina que parece ser a mais correta, é ponto incontroverso que a idéia da unificação não tem por efeito eliminar a autonomia didática e científica do direito comercial e do próprio direito civil, segundo BULGARELLI ${ }^{38}$ e mais proximamente Norberto MACDONALD ${ }^{39}$.

Para ranto, o direito comercial tem características próprias (simplicidade, rapidez, onerosidade, elasticidade, internacionalidade), que retratam o dinamismo do comércio, em contraste com a estática do direito civil ${ }^{40}$. Um considera os bens pelo valor de troca e o outro pelo valor de uso, por exemplo.

Como foi visto, o sub-título antecedente tetratou a idéia da unificação das obrigações civis e comerciais, agora realidade, mas que é fruto de pensamento jurídico evolutivo que teve início com os estudos de Augusto Teixeira de Freitas. Tal inovação anteriormente não havia sido possível devido a vários fatores, tal como a precedència de um Código Comercial a um Civil e mesmo a demora na aprovação deste último.

Ainda, foi obsetvado que nem por isso a autonomia conquistada pelo direito comercial, ainda que $\mathrm{cm}$ sua versão mínima, acadêmica e científica, deixou de existir, em que pese tenha sido questionada.

Contudo, somente o funcionamento do novo sistema obrigacional unificado permititá uma conclusão mais precisa.

A seguir será vista a posição assumida pelo direito da empresa no novo Código, bem como as ferozes críticas a esta configuração.

\footnotetext{
${ }^{36}$ BULGARELLI, W. Contratos mercantis, p. 48.

${ }^{37}$ MARTINS, F. Curso de direito comercial: empresa comercial, empresários individuais, microempresas, sociedades comerciais, fundo de comércio, p. 23.

${ }^{38}$ BULGARELLI, W. Tratado de direito empresarial, p. 211.

${ }^{39}$ MAC-DONALD, N. da C. C. O projeto de Código Civil e o Direito Comercial.

${ }^{40}$ MARTINS, F. Contratos e obrigações comerciais, p. 9.
} 


\section{B. Direito da empresa no novo Código}

Como anteriormente referido, sem solução de continuidade, o novo Código Civil apresenta, após a disciplina do direito das obrigações, a normatização do direito da empresa. Trata-se de regramento que consta pela vez primeira numa codificação civil brasileira. Devido a isso e pelo fato de a regulamentação da reotganização das empresas estar ali também disciplinada, este tópico trará algumas considerações sobre a inclusão não somente das obrigações em um regramento civil único, mas também do direito da empresa, alternativa que pode ter rornado este um mero ramo do direito civil, assim como o da família, o da sucessão, etc. Por fim, serão arroladas diversas críticas ofertadas pela mais especializada doutrina a esta junção.

Com efeito, o então Projeto destinou diretamente 227 artigos ao regime da atividade negocial, decompostos em quatro títulos e dois subtítulos. Assim que o Livro II, da Empresa, em seu Título II, da Sociedade, aptesenta estas como simples (que são as antigas sociedades civis $^{41}$ ) e empresárias, personificadas e não personificadas (classificação que engioba as atuais sociedades de fato e pretende diminuir a confusão que reina ${ }^{42}$ ). Cada uma das sociedades ali admitidas vem acompanhada de um tratamento específico.

Já no Subtítulo II, da Sociedade Personificada, vem o novo Código, por seu Capitulo $\mathrm{X}$, tratar da transformação, da incorpotação e da fusão e cisão das sociedades, especificamente nos artigos 1.113 a 1.122. Vale lembrar que o estudo detalhado desta regulamentação é o objetivo principal aqui pretendido e será feito na segunda parte deste trabalho.

Ainda durante a fase de emendas ao Projeto, da Atividade Negocial o Livro passou a se chamar do Direito da Empresa, dando nova face ao direito comercial, que deverá se voltar pata a empresa. Ocorre que a inclusão do diteito da empresa em uma regulamentação civil fez com que para muitos esse campo do direito passasse a constituir um meto ramo do direito civil, ao lado do direito obrigacional, da família, etc. Mas, como foi visto, esta idéia foi veementemente contestada por BULGARELLI, para quem o direito mercantil mantém vivo a sua autonomia com princípios, método e conteúdo próprios ${ }^{43}$.

Noutro momento o noso Código regulou questões relativas ao registro, nome, prepostos e escrituração. Certamente numa sociedade de economia de massa, que reconhece a empresa como a forma de evolução na técnica de produção e distribuição de bens e serviços, a intervenção do Estado ao exigir registro não é excrescência intervencionista ${ }^{44}$, conforme BULGARELLI.

\footnotetext{
${ }^{41}$ BULGARELLI, W. Op.cit., P. 264.

${ }^{42}$ Idem, p. 267.

${ }^{43}$ Idem, p. 196 e BULGARELLI, W. Contratos mercantis, p. 48-51. Neste sentido ainda MARTINS, F. Curso de direito comercial: empresa comercial, empresários individuais, microempresas, sociedades comerciais, fundo de comércio, p. 23.

44 BULGaRELLI, W. Tratado de direito empresarial, p. 225.
} 
: le lembrar que o Código, inspirado no sistema alemão, facultou da inscrição o pequeno mpresário e o empresário rural, dispensando-os das obrigações, deveres e restrições impostas os empresátios inscritos. A crítica que merece ser feita a esta tomada de posição é que a facultatividade da inscrição impedirá a aplicação da Lei das contravenções penais aos ambulantes e aos marreteiros dos grandes centros populacionais, bem como desprotegeráo empresário quanto a marca e símbolos da empresa ${ }^{45}$.

Também o novo ordenamento manteve ao pequeno empresário a dispensa expressa da mantença de escrituração e de livros.

Observa-se, igualmente, uma nova apresentação conceitual de alguns institutos antigos, tais como empresa, empresário e ato de comércio. Assim, COUTO e SILVA definiu o conceito de empresa e sua aplicação no Projeto e na Lei das Sociedades Anônimas em seu clássico artigo $O$ Conceito de emptesa no direito brasileiro, esclarecendo que este sofreu forte influência do direito italiano ${ }^{46}$. Em verdade, segundo o jurista gaúcho, o conceito de empresa supera a distinção entre os direitos obrigacionais, constituindo fator importante para a unificação ${ }^{47}$. Mas em conclusão o autor assevera que não há urn conceito unitátio de empresa ${ }^{48}$.

Já quanto ao conceito de empresário (que vem no artigo 969) como sendo aquele que exerce profissionalmente atividade econômica organizada para a produção ou circulação de bens ou serviços, COUTO e SILVA lembra que ele reflete com exatidão o disposto no artigo 2.082 do código civil italiano ${ }^{49}$.

No Código se vê nitidamente o abandono da figura do empresário comercial, e sua troca pela disciplina jurídica da empresarialidade $e^{50}$ e do estabelecimento, com o que, desta vez, se afastou da linha do código italiano, mostrando assim sua originalidade ${ }^{33}$, já antes defendida por REALE. Mas em análise mais particular representa um verdadeiro aperfeiçoamento daquele em termos técnico-jurídicos, tendo havido também um ajustamento à realidade brasileira ${ }^{52}$, o que era normal, já que sua redação final se dava há mais de 30 anos daquele, que não por isso deixou de the inspirar em muitos pontos.

Por firn, vale referir que o tormentoso e jamais determinado conceito de ato de comércio, segundo BULGARELLLI, é substituído pelo de empresa, bem como a categoria de fundo de comércio cede lugar à de estabelecimento ${ }^{53}$, todos em combinação com o novo conceito de empresário, que afasta também o de comerciante, segundo o artigo 969. Por isso a analogia ao código civil italiano deve ser evidenciada.

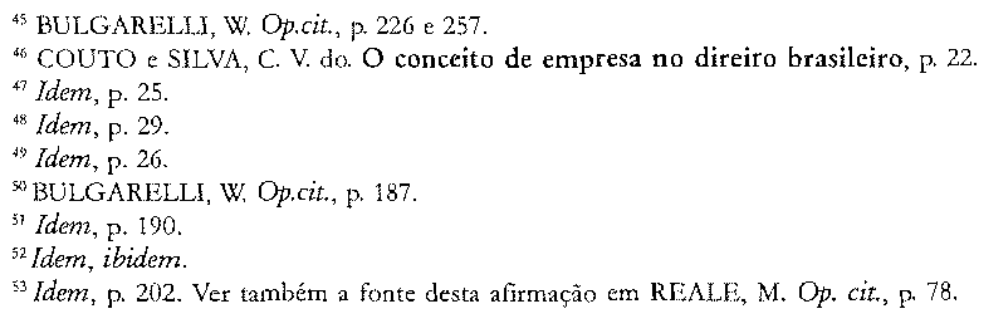


Isto posto, mesmo que em aspectos gerais, esta seção do estudo seguirá retratando uma série de críticas oferecidas pelos estudiosos pátrios contra a inclusão do direito da empresa no novo Código, pelo menos da maneita pela qual foi feita, que julgam ter sido parcial elacunosa.

Inicialmente, cabe dizer que a adoção da teoria da empresa ${ }^{54}$ sem ressalvas poderá fazer com que, pouco a pouco, as pequenas explorações, fracas de recursos, sejam substituidas por grandes conjuntos de produção e distribuição.

Já Fábio Konder COMPARATO diz que o Livro consagrado à disciplina dos empresátios e das sociedades surge como um copo estranho no Código, sem uma ligação interna e necessária com as dernais partes da obra ${ }^{55}$. Também para o autor os contratos empresariais, no livro das obrigações, apresentam-se, salvo exceçōes, mal regulados ${ }^{56}$. Contudo, assevera por final que estão bem melhor que na proposta de 1965.

Rubens REQUIÃO, citado por BULGARELLI, tece as críticas mais fortes à reunião da matéria civil e comercial no mesmo então Projeto. Segundo o autor, se assim foi com Teixeira de Freitas, os tempos modernos impõem a fragmentação legislativa ${ }^{57}$, ou como quer Ascarelli, o fracionamento ${ }^{58}$, ao lembrar que na Itália há, inclusive, um Código da Navegação separado do Civij ${ }^{59}$. Lembra ainda que a Suiça e a Itália foram movidas por idéias políticas e ideológicas presentes a época em que promoveram as suas unificações. Mas nos últimos 30 anos a Alemanha, a França, Portugal, Argentina (com a lei das sociedades comerciais), Colômbia e o México estabeleceram dualidades ao menos nas matérias relativas às sociedades.

Para Norberto MAC-DONALD, tal sistematização frustrou expectativas no tocante a inovações ${ }^{60}$. Deixou, por exemplo, de regular novos contratos que já estão ern uso, entre a população, há muito tempo ${ }^{61}$.

Deixou de introduzir a limitação da tesponsahilidade do empresário individual ${ }^{62}$, o que vem sendo referido como o instiuto do destacamento, já que perdeu a oportunidade de disciplinat sohre as Empresas Individuais de Responsabilidade Limitada ou sociedades unipessoais $^{63}$. Claro que este assunto nunca foi pacífico em direito brasileiro, mas não é de

\footnotetext{
54 Sobre a substituição da teoria dos atos de comércio pela da emapresa é conclusão a que chega MACDONALD, N. da C. C. Op.cit., p. 157.

${ }^{55}$ COMPARATO, Fábio Konder. Atualidades, p. 177.

5x Idem, ibidem.

${ }^{57}$ BULGARELLI, W. Op.cit., p. 217-219.

${ }^{58}$ Citado por MAC-DONALD, N. da C. C. Op.cit., p. 141.

${ }^{59}$ Reterência que também faz M $\Lambda$ C-DONALD. Idem, ibidem.

${ }^{610} \mathrm{Idem}, \mathrm{P} .157$.

${ }^{61}$ BULGARELLI, W. Op.cit., p. 217.

"2 Idem, p. 271. Sobre o assunto ver o trabalho de ARAUJO por nós orientado. ARAUjO, Jair Sidnei Freitas de. Responsabilidade do Comerciante Individual.

${ }^{63}$ Por todos, ver o assunto em SALOMAO FILHO, Calixto. A sociedade unipessoal e ainda em GAVIRIA GUTSERREZ, Enrique. Sociedad unipersonal o empresa unipersonal.
} 
olvidar que as adotaram o Peru, em 1976 e a Costa Rica, em $1969^{64}$. Tais empresas foram também adotadas na Alemanha (com a Lei de 4 de julho de 1980), após profundos estudos desencadeados na Universidade de Heidelbetg. Mais recentemente, observou-se esta disciplina na França (com a Lei 85-697, de 11 de julho de 1985) ${ }^{65}$, e em Portugal e Itália, Bélgica, Holanda, Dinamarca e no Paragua ${ }^{j 66}$.

Já disse COUTO e SILVA em 1986 que se discutia com vigor a respeito da sociedade unipessoal no mundo inteiro ${ }^{67}$. No Brasil é objeto de Projeto de Lei sobre Empresa Individual de Responsabilidade Limitada, de autotia do Departamento Nacional de Registro e Cadastro do Comércio, que está no Senado Federal desde agosto de $1994^{18}$. Mas o novo Código preferiu não acolher as sociedades unipessoais, ainda que COUTO e SILVA teconhecera sua progressiva admissã $0^{69}$, pois o conceiro de sociedade pressupõe a existência de no mínimo dois sócios. Como pensat, então, em sociedade de um homem só ${ }^{70}$ ?

A inclusão do direito da empresa no Código Civil tornou sua eficácia discutivel pois também não afastou a possibilidade de existirem sociedades de homens de palha, ou de

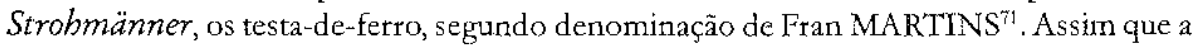
nova regulamentação não demonstrou como coibitá a presença destes, também conhecidos como ficcionistas.

Na seqüûncia das críticas, o ponto do direito da empresa no novo Código regulamentou apenas superficialmente as sociedades coligadas, chamando-as de "ligadas", e silenciou em relação às uniões pessuais, aos contratos interempresariais e aos consórcios.

${ }^{64}$ A responsabilidade limitada do comezciante individual é reconhecida legalmente no Peru pela L.ei número 21.621, de 14 de setembro de 1976. Também o Código de Comércio da Costa Rica, com a reforma da Lei número 4.327, de 17 de fevereiro de 1969, admitiu e tegulou a empresa individual de responsabilidade limitada. MARTINS, F. Op.cit., p. 335.

65. Idem, p. 135-136.

${ }_{60}$ A regulamentação noutros países pode ser encontrada em ARAUJO, J. S. F. de. Op.cit., p. 21 e detalhadamente nas páginas 33 41.

${ }^{67}$ COUTO e SILVA, C. V. do. Op.cit, p. 27.

${ }^{68}$ Pontualmente analisado em ARAUJO, J. S. F de. Op.cit, p. 7 e 22-29.

${ }^{59}$ COUTO e SILVA, C. V. do. Op.cit., p. 27.

"Segundo MARTINS, "O direito brasileiro está dando passos positivos para o reconhecimento pleno da separação do patrimônio do comerciante individual. Assim, deve este fazer duas declarações de renda, uma como pessoa física e outra como comerciante. Isso significa que a própria lei reconhece que há um patrimônio do comerciante individual diverso do patrimônio particular da pessoa física que exerce o comércio. Por outro lado, se o comerciante individual vende um imóvel que está contabilizado como fazendo patte do seu acervo comercial, não necessita da outorga uxória, indispensável nas transações sobre imóveis de pessoas casadas". MARTINS, F. Op.cit., p. 335. Neste sentido o novo Código Civil brasileiro onde, qualquer que seja o regime de bens, o empresário (a) casado (a) não depende da outorga conjugal para vender imóveis do patrimônio da empresa. EBOLX, Exandro. Presidente sanciona hoje o novo Código Civil. O Globo. Rio de Janeiro, 10 jan. 2002, p. 11.

"MARTINS, F. Op.cit., p. 315. 
Já quanto à importante questão da desconsidetação da personalidade jurídica ${ }^{72}$, apresentou um dispositivo ${ }^{73}$ muito restrito e tímido no artigo 50 , em nada se aptoximando dos profundos estudos do professor de Heidelberg Rolf Setick. Vale lembrar que há disposição muito mais agressiva no Código de Defesa do Consumidor, por seu artigo 28 e na cópia que lhe fez o artigo 18 da Lei da Concorrência brasileira, disposições que em momento algum justificam a lacuna deixada no Código Civil.

Waldirio BULGARELLI entende ser ele merecedor de crítica também pelo fato de a falência civil não ter sido instituída e tampouco unificada ${ }^{74}$, no sentido de poder ser decretado o mesmo instituto para a pessoa civil. Ou, não sendo possível esta hipótese máxima, ao menos tivesse regulado a falência comercial do menor de idade que exerce atos de comércio mesmo sem registro legal.

Também entende o renomado autor, em críticas mais vecmentes, que o regime da empresa não deveria estar inclúdo no Projeto ${ }^{75}$, e agora tampouco no Código, e sim constituir uma Lei Geral para as Sociedades, ou um Código de sociedades, idéia que tem amparo na Emenda de número 562, a ela tendo se teferido. Desta forma, a unificação se daria somente no âmbito das obrigações, que na verdade é matéria comum, e traz a vantagem da coordenação sistemática, permitindo um ajustamento melhor à parte geral $^{76}$.

Lembra ainda BULGARELLI que bavia uma Emenda de número 304, do então depurado Tancredo Neves, propondo a retirada do direito das obrigações para compor um código próprio 77 .

Por outro lado, no documento há uma total falta de atenção ao consumidor, para o qual nenhum dispositivo está expressamente ditado, assim podendo tê-lo feito com uma diretriz mais definida nos casos dos vícios redibitórios e da responsabilidade civil ${ }^{78}$. Patece até não ser um Código voltado para uma sociedade industrial em que a empresa detém o poder e impera o consunismo ${ }^{79}$ !

\footnotetext{
${ }^{72}$ Sobre o assunto vet os trabalhos de GOMES, Yaná Christina Eubank. A teoria da desconsideração da personalidade jurídica e a responsabilidade dos sócios, gerentes e administradores de empresas nas sociedades comerciais, em face do Código de Proteção e Defesa do Consumidor, de GIARYiTA, Gerci. Teoria da Despersonalização da Pessoa Jurídica, de PINHO, Luciano Fialho de. A desconsideração da personalidade jurídica e a proteção do consumidor no Código de Defesa do consumidor, de LIMA, Osmar Brina Corrêa. A teoria da desconsideração da personalidade jurídica descomplicada, e de HENTz, Luiz Antonio Soares. Notas sobre a desconsideração da personalidade jurídica: a experiência portuguesa.

${ }^{73}$ Sobre a inclusão deste no Código ver MAC-DONALD, N. da C. C. Op.cit., p. 158.

${ }^{74}$ BULGARELLX, W. Contratos mercantis, p. 51.

${ }^{75}$ BULGARELLI, W. Tratado de direito empresarial, p. 191.

${ }^{75}$ Idem, p. 199.

"Idem, p. 192-193.

${ }^{78}$ Idem, p. 208-209.

${ }^{79}$ Idem, p. 206.
} 
Da mesma forma deixou de estabelecer a função social da empresa, que se pode pensar valer somente para as anônimas, pois lá a lei assim se refere $e^{80}$.

Não bastasse o que já foi referido, o Código manteve em documentos apartados a legislação do anonimato, isto é, o regime das sociedades anônimas, parcialmente influenciada pela legisłação alemã de $1967^{81}$, bem como a legislação das limitadas, entre outras. Ocorre que o documento referido apenas fixa linhas gerais, e a regulamentação específica é remetida às leis espectais, segundo disposição expressa do artigo 1089, do novo Código Civil.

Entre os autores que não consideram esta a melhor solução técnica de normatização de um assunto, encontra-se Norberto MAC-DONAL D ${ }^{82}$. Também, a decisão governamental de excluir estas matérias do Código, segundo COMPARATO, veio tornat ainda menos defensável a manutenção dessa disciplina da atividade negocial num mesmo documento ${ }^{83}$. Tal deveut-se ao fato de esse tipo societário (o do anonimato) ainda estat em aperfeiçoamento, como comprovavam as tentativas de alteração da sua lei no Brasil.

Ainda, por fim, outros pontos criticáveis são o fato de o Código não ter se referido às cooperativas, o que prova que a idéia de um Código de Sociedades não é tão descabida, não ter reproduzido, nem em regra geral, como fez com a reorganização das empresas, o regramento da falência, da propriedade industrial, da concorrência, do registro público das atividades emptesariais e afins, do transporte marítimo e do transporte aetonáutico.

Ao contrário, optou por manter outros tratamentos flagrantemente desnecessários, como a regulamentação de sociedades em desuso. Por quê continuar a tratar delas?

A manutenção do trato de algumas matérias em documentos apartados ${ }^{84}$ e a própria existência revivida destas leis (como a da sociedade anônima, que sofre remissões ${ }^{85}$ pelo Código, e a da sociedade por quotas de responsabilidade limitada) que tratam das questões marginalizadas pelo Código faz pensar que a idéia da mictossistematização está bem viva e fará com que o Código, nem bem vigente, precise ser revisto, conforme previsão de BULGARELLI ${ }^{86}$.

"1dem, p. 207.

REALE, M. Questões de direito privado, p. 86.

B2 MAC-DONALD, N. da C. C. Idem, p. 155.

${ }^{83}$ COMPARATO, F. K. Idem, p. 177.

${ }^{84}$ A exclusão do regularnento das sociedades por açōes do âmbito do Código Civil modiffcou a anterior orientação do Anteprojeto e conservou a atualmente em vigor, segundo MAC-DONALD. MAC-DONALD, N. da C. C. Op. cit., p. 158.

${ }^{85}$ Em especial a do artigo 1.089 sobre a regulação da sociedade anônina, a qual é cometida à lé especial. Idem, p. 141-142.

я6 BULGARELLI, W. Op. cit., p. 272. 
Em conclusão parcial, após ter sido retratado o surgimento do novo Código Civil brasileito, documento que unificou as obrigações civis e comerciais e trouxe incluso un Livro destinado à Empresa, na segunda parte foram trazidas algumas considerações sobre a inclusão do direito da empresa em um regramento civil, bern como una séric de alterações conceituais com ela promovidas.

Como se viu, especialmente pelas veementes defesas de doutrinadores pátrios, tal sistematização não conseguiu tơnar o direito negocial um mero ramo do direito civil, já que ele manteve sua autonomia própria.

Outra questão a qual se ateve este estudo foi repetir uma série de críticas a determinados aspectos materiais por terem ou não sido trarados pelo Código, como por exemplo a doutrina do disregard, que o foi, mas de forma tímida, a não regulamentação da sociedade unipessoal e, principalmente, por ter o Código optado por um sistema de previsão geral, mantendo em vigor leis específicas esparsas.

Mas o que interessa para o seguimento deste estudo é que o novo Código Civil tratou dos processos de fusão, incotporação e outras formas de reorganização societátia, o que será visto a seguir. Contudo, tal referência se deu em linhas gerais, pois a regulamentação específica segue sendo determinada pela lei das sociedades anônimas, onde até agora a matéria estava unicamente tratada.

\section{PARTE 2}

\section{CONCENTRAÇÕES E DESCONCENTRAÇÕES EMPRESARIAIS}

Antes de serem indicadas nessa parte as formas e fases de compenetração de empresas, imperioso se faz estudat o fenômeno concentracionista e sua relação com a disciplina da concorrência e com o interesse dos consumidores, pois os seus efeitos no metcado são comuns, independentemente da forma escolhida pela empresa.

Diversos são os elementos ponderados por elas no momento da manifestação do interesse concentracionista, sendo que os principais são a diminuição de custos e a viabilização de novos mercados.

A questão que umbilicalmente deverá ser referida é a da disciplina da concorrência, já que esta é profundamente alterada com a concentração de empresas. No Brasil tal controle está afero ao Conselho Administrativo de Defesa Econômica (CADE), órgão que recebe as denúncias sobre empresas que pratiquem condutas típicas que limitem a concorrência. Vale lembrar, como será visto a seguir, que existem condutas que podem ser aprovadas mesmo que sejam anticoncorrenciais, especialmenre se estiverem em conformidade con o interesse dos consumidores. 
Então, inicialmente serão configuradas características dos processos de teorganizações de empresas e posteriormente as formas e fases específicas de manifestação deste fenômeno admitidas pelo novo Código Civil brasileiro.

\section{A. Fenômeno concentracionista e concorrência}

O surgimento do que será considerado um fenômeno concentracionista não é recente. Pelo contrário, tem origem muito remota, lá na Antigüidade, mas cujos reflexos se manifestaram mais modernamente na Revolução Industrial.

A manifestação atual deste fenômeno é devida à internacionalização das economias nacionais, materialmente integradas pela revol ução nos transportes e nas comunicações ${ }^{87}$, e se processa no fato das empresas serem forçadas a realizar ajustes e formar alianças de concentração para ampliat a economia de escala e a sinergia, com vistas a uma melhor sobrevivência e enfrentamento dos novos tempos competitivos ${ }^{88}$.

Mas não somente estes elementos movimentain o fenômeno. Também a conquista de novos mercados, especialmente se motivada por benefícios fiscais ${ }^{84}$, é verificada.

A concentração de empresas também permite a elas racionalizar a produção e a administração do negócio, mais facilmente adotar os progressos tecnológicos e desenvolver cabedais, reorganizar as estruturas, evitar a concorrência e acessar investimentos de grande vulto $^{90}$. Não fosse o bastante, ainda pode desencadear uma transferência de tecnologia, a viabilização de novos mercados, facilidades tributárias e fiscais, um mais eficiente controle de matérias-primas, um mais racionalizado uso de mão-de-obra e a divisão de riscos e de lucros entre coligadas.

A empresa, ao assim agit, busca um ambiente que acredita possa vir a ser-lhe favorável, por garantir eficiência alocativa e produtiva, preços mais baixos, produtos mais abundantes ${ }^{91}$ e outras alternativas válidas, tal como a de internacionalizar a produção.

\footnotetext{
${ }^{87}$ MAGALHÃES, José Caxlos de; SAMPAIO, Onofre Carlos de Arruda. A concentração de empresas e a competência do CADE, p. 30.

${ }^{88}$ Idem, $\mathrm{p}$ 31, CARVALHO, Patrícia. Joint Venture: um olhar voltado para o futuro, p. 165 e SQUASSONI, Christian Max Finardi. O direito de continuar sócio de S/A face às reorganizações societárias, p. 140 89 Sobre o assunto ver o recurso especial número $242.721 / \mathrm{SC}$, segundo o qual a "transformação em qualquer de suas facetas das sociedades não é fato getador de ICMS".

${ }^{*} \mathrm{VAZ}$, Isabel. Os interesses do consumidor nas fusões e incorporações de empresas, p. 226 e LEÃES, Luiz Gastão Paes de Barros. Incorporação de companhỉa controlada, p. 88.

${ }^{91}$ LOPES, José Reinaldo de Lina. Direito da concorrência e direito do consumidor, p. $87 .$.
} 
Sem dúvida, dois dos principais fatores motivadores são a necessidade de redução de custos e a melhoria de qualidade para competir. $\mathrm{O}$ atingimento deste nível desejado tem como conseqüência a ampliação dos luctos, a criação de empresas mais competirivas, mais capitalização e qualidade, além de apresentar um equilibrio do balanço de pagamentos e uma estrutura logística consolidada, tudo num propósito que pode ser o de fugir à absorção pelo capital estrangeiro.

Em verdade, este fenômeno é fundado em haver uma consciência que a empresa só poderá sobreviver no longo prazo efetuando uma reorganização societária, seja através da entrada de novo sócio nacional ou estrangeiro, fusão ou aliança estratégica ${ }^{92}$.

Segundo o pensamento empresarial, tais práticas são os resultados das inevitáveis exigências ligadas às conjunturas do mercado e à necessidade de coordenat esforços para satisfazer a demanda dos altos investimentos requeridos pelo progresso tecnológico ${ }^{93}$.

Então, assim como outros países, o Brasil tem registrado um número crescente de metamorfoseamentos, fusões e aquisições de empresas tealizadas com o objetivo primordial de incrementar a competitividade local ou intennacional, diante do fortalecimento de concorrentes em ambas as esferas, sobretudo no exterior, segundo MAGALHÃES e SAMPAIO ${ }^{94}$.

Não suficientemente satisfeitas com os objetivos acima declinados, como a meta intenção de crescer, a concentração de empresas passou a assumir variados motivos. Neste sentido inúmeras leis concederam estímulos como isenção de imposto de renda sobre a reavaliação do imobilizado e a não incidência de impostos sobre o aumento de capital. Devido a isso algumas empresas encontratam nos benefícios fiscais os principais atrativos para a reorganização.

Para as futuras manifestações do fenômeno já se pensa numa atividade empresarial concentrada em disputa entre blocos econômicos, como a ocorrida com a fusão da empresa americana Boeing com a McDonald Douglas, ato que foi contestado pela União Européia, o que vem modificar o quadro atual, no qual prevalece o enfoque de defesa da concorrência no mercado nacional e interno ${ }^{95}$.

As concentrações de empresas tecebem uma classificação doutrinátia ${ }^{96}$. Ellas podem se classificadas em horizontais, quando se verificam entre agentes econômicos situados na mesma fase do processo produtivo (luta contra as concorrentes diretas), verticais, quando se

\footnotetext{
${ }^{22}$ CARVALHO, P. Op. cit., p. 163.

${ }^{93}$ REALE, M. Op. cit., p. 85.

"MAGALHÃES, J. C. de; SAMPAIO, O. C. de A. Op. cit., p. 39.

${ }^{25}$ Idem, P, 41.

${ }^{26}$ VAZ, I. Op. cit., p. 227-228.
} 
operam entre agentes situados em diferentes etapas do processo, desde que não sejam concorrentes entre si, e conglomerados ${ }^{97}$, situados em uma categoria tesidual, reunindo as concentrações que não se enquadram nem na primeira categoria nem na segunda. Há autotes que se referem ainda às concentrações diagonais ou de natureza fiscal, assunto que não será explorado.

Isto posto, há uma questão diretamente telacionada com a concentração de empresas que é a da disciplina da concorrência"s.

Os Estados Unidos da América são um país que, ao contrátio do Btasil, sempre preservaram a livte iniciativa e a concorrência como valores fundamentais da nação ${ }^{* 9}$. Já aqui, fatores recentes como a abertura das fronteiras e a conseqüente admissão das importações em geral (imposta até pelo sucesso da Rodada Uruguai do GATT) e o abandono da prática das suibstituições de importações, bem como a estabilização monetária, a privatização das empresas estatais, a globalização e o fim da vida útil da geração dos primeiros empresários brasileiros ${ }^{106}$ deram novos contornos à legislação antimonopólio ${ }^{10 !}$.

Então em momento oportuno ${ }^{162}$ a Constituição Federal de 1988 optou pela livre iniciativa e pela não-intervenção do Estado na economia, princípios que estão estabelecidos no artigo 170 e seguintes, onde também se encontran os incisos teferentes à defesa do consumidor, à função social da propriedade, defesa da concotrência e ao meio ambiente, em igualdade hicrárquica.

Esta proximidade entre defesa do consumidor e da concorrência já era notada em 1951 com a definição dos crimes contra a economia popular, cujo documento pode ser entendido como um diploma de defesa do consumidor ou da concorrência da época ${ }^{1 / 33}$. E a atual lei da concorrência mantém esta aproximação ao incluir no artigo $1^{\circ}$ o propósito de defesa do consumidor.

Esta relação pode ser melhor entendida com a lembrança de que a prática de um só ato pode configurar violação ao Código de Defesa do Consumidor, concorrência desleal e incidência do Código de Propriedade Industrial, além de configurar abuso de poder econômico.

\footnotetext{
97 PONSBCA, José Júlio Borges da. Disciplina da concorrência nas operações de concentração empresarial, p. 30.

${ }^{98}$ Sobre os órgáos responsáveis pela tutela deste direito no Brasil ver o trabalho de conclusăo de curso de graduação em Direito de KERN, por nós orientado. KERN, Adriana Silvia Klein. Direito da Concorrência no Brasil: evolução normativa e órgãos responsáveis pela sua tutela.

${ }^{99}$ MAGALHĀES, J. C. de; SAMPAIO, O. C. de A. Op. cit., p. 30.

'CARVALHO, P. Op. cit., p. 162.

10. MAGALHÃES, J. C. de; SAMPAIO, O. C. de A. Op. cit., p. 31.

102 Segundo MAGALHÃES e SAMPAIO, "os longos anos de prática intervencionista deixaram marcas profundas que a Nação resolveu apagar (...)”. Idem, p. 32.

LOPES, ]. R. de L. Op, cit., p. 80.
} 
Neste sentido, a Lei $8.884 / 94$, tendo reiterado os princípios constitucionais no seu artigo $1^{\circ}$, veio ainda regular o controle de atos c contratos que possam limitar ou prejudicar a livre concortência ou resultem na dominação de mercados relevantes de bens ou de serviços, como visualizado no artigo 54. Esta limitação é geralmente advinda como consequuência das reotganizações empresariais.

Adentrando um pouco mais na legislação brasileira de concotrência acima mencionada, observa-se que ela versa sobre a defesa da concorrência, e não pelo estímulo a ela ${ }^{104}$. Assim, esta lei não acolheu a teoria da concorrência potencial ${ }^{105}$, aplicada para estinular e não para defender a concorrência, pois em última análise ela pretende que a empresa interessada em participar de um mercado novo o faça individualmente, por si própria, ou mediante a constituição de uma subsidiária, com o que acirratá a concorrência local, segundo MAGALHĂES E SAMPAIO ${ }^{106}$. Assim prevê que una fusão somente seja condenada quando ela não aumentar a concorrência, quando não provocar o estresse da concortência, o que faz a fusão como estímulo e necessidade de aunnento da concorrência valorada positivamente ser uma busca constante nos ordenamentos que a adotam.

Portanto, no Brasil, não havendo limitação à concortência existente, ou ainda que tal ocorra, estando preenchidos os pressupostos do artigo 54 (essencialidade para a econonia e não prejúzo ao consumidor final), a reorganização é aprovada, mesmo que a concorrência no mercado não venha a ser aumentada.

Caso o Brasil adotasse essa teoria, o caput do artigo 54 deveria dizer que "setão submetidos à apreciação do CADE os atos que não impliquem em aumento substancial da concorrência", e não como hoje é disciplinado, devendo serem autorizados mesmo aqueles que possam limitar a concorrência. Por não ser como acima declinado, o CADE se limita a sua previsão constitucional de não aplicat teorias destinadas a impulsionar a concorrência ${ }^{10 \%}$.

Como exemplo de condutas típicas que limitam a concorrência, tem-se a venda casada, a cartelização, o açambatcamento de mercadorias, a fixação de preços de revenda, a retenção de bens de produção ou de consuno, a criação de dificuldades às empresas concorrentes e a imposição de preços excessivos ${ }^{1 / \%}$, entre outras menos sensíveis.

\footnotetext{
TH MAGALFÃES, J. C. de; SAMPAIO, O. C. de A. Op. cit., p. 42.

t25.5 Nem a teoria alenã da criação on fortalecimento de posição dominante no mercado, que gira em torno do conceito de criação de posição dontinante ou seu reforço. FONSECA, ). J. B. da. Op. cit., p. 33-34.

"UAGALHÃES, J. C. de; SAMPAYO, O. C. de A. Op. cit., p. 43.

in $O$ fato de o CADE não insistir na aplicação de teorias destinadas a impulsionar a concorrência prejudica a livre inficiativa. Idem, p. 44.

!'Is VAZ, I. Op. cit., p. 221.
} 
En tão a atuação do CADE, uma espécie semelhante ao Bundeskartellamt alemão: ${ }^{109}$, é subordinada à lei, qualificando-se seus atos como atos vinculados da Administração, e por tal não dispondo o administrador de ampla liberdade de decisão, segundo MAGALHÃES e SAMPAIO ${ }^{110}$. Esta atuação pode ser de caráter preventivo, examinando os atos de concentração capazes de alterar significativamente o equilíbrio das forças de mercado, nele provocando distorções, ou repressivo, cuja ação ocorre após a ocorrência de um ato ou conduta julgados lesivos à concorrência e aos direitos do consumidor ${ }^{111}$.

O controle promovido pela instituição visa manter desconcentradas as estruturas de mercado, de modo a reduzir a autonomia excessiva de alguns participantes, incrementar a concorrência, a competição, a melhoria da qualidade dos produtos e serviços e beneficiar, com a redução de custos, o consumidor final. Assim os atos somente serão aprovados se ficar demonstrado que a transação acarteta beneficios para o consumidor maiores do que as eventuais testrições à concorrência ${ }^{1 / 2}$.

Vale lembrar que a reorganização pode decorrer de uma necessidade de o país fortalecer suas empresas, necessidade que precisa ser equilibrada com a de defesa da concorrência e do consumidor. Segundo esta argumentação, duas empresas, ao reunirem seus patrimônios, seus esforços, suas tecnologias, podem auferir ganhos de escala maiores que se operassem de forma isolada ${ }^{113}$.

Não há dúvida que a concentração de empresas acarreta o fortalecimento da economia de uma nação, mas não se pode descurar os direitos do cidadão enquanto consumidor ou usuário de bens e serviços ${ }^{114}$. Por outro lado, os intetesses do Estado não podem sobreporse aos direitos dos consumidores e ao direito de acesso ao consumo ${ }^{115}$. Então estes limites são de análises por demais estreiras. Pode haver a situação que, mesmo sendo lesionado, o valor maior a set pesado é o ato de disponibilizar o ptoduto no mercado consumidor.

Antigamente se pensava que a fusão era um "ilícito $\mathrm{em} \mathrm{si",} \mathrm{isto} \mathrm{é,} \mathrm{fusão} \mathrm{como} \mathrm{sendo}$ sempre um ilícito ${ }^{\mathrm{ji}}$. Hoje já se observa que há hipóteses onde o consumidor é mais beneficiado, mesmo que haja a retirada de um agente do mercado, reduzindo desta maneira suas possibilidades de escolha. Nos Estados Unidos da América esse procedimento permissivo é a regra da razão (Rule os reason, de 1911), segundo a qual passaram a ser condenadas apenas as restrições desarrazoadas à concorrência ${ }^{11}$.

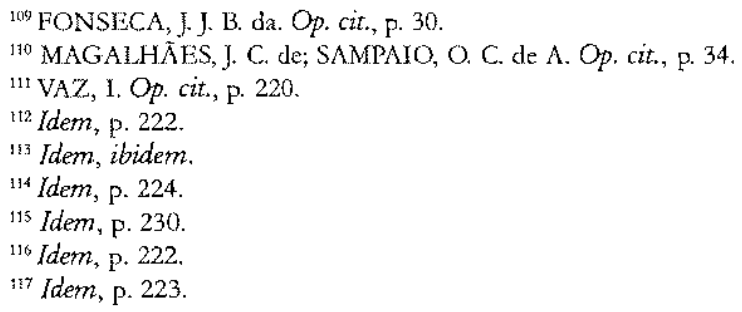


Dentre outras situações conhecidas como condutas anticoncorrenciais autorizadas, encontra-se o fortalecimento da indústria nacional, o que justifica uma fusão, o aumento da produtividade, a meihoria da qualidade, o desenvolvimento tecnológico ou econômico, as práticas fundadas em motivo preponderante para a economia nacional e os benefícios eqüitativos entre empresas e consumidores frnais ${ }^{118}$, como redução dos preços e aumento da eficiência. Vale lembrat que muitos desses elementos são os mesmos buscados pelas empresas quando tomam a decisão de se submeterem a processos de reorganização.

Sobretudo, as eventuais concentrações sefão aprovadas especialmente se estiverem em conformidade com o interesse do consumidor. Ocorre que o processo de privatização, parte de uma diretriz aceita pelo Brasil, que tinha como objetivo a inserção da econômica nacional em um mercado mundializado, promoveu uma abertura da economia brasileira ${ }^{119}$ aos investimentos estrangeiros no país, com privilégios, créditos e facilidades jamais outorgadas aos empresátios nacionais. Assim, os interesses do consumidor agora não estão apenas em face dos produtores nacionais, mas em face de gigantescos conglometados estrangeiros também ${ }^{i 20}$.

Qualquer reorganização de empresas, ato ou contrato se torna suscetivel de, em tese, afetar os interesses do consumidor, pois toda fusão ou incorporação acarreta a supressão de um ou mais agente econômico no mercado, teduzindo as oportunidades de escolha do consumidor ${ }^{121}$. Conforme a dimensão da operação ${ }^{122}$, sendo ela capaz de provocar distorções nos mercados e afetar a livre formação dos preços, independentemente da forma de sua manifestação, isto é, estando ou não prevista na lei do anonimato ${ }^{123}$, ela ptecisa ser levada à aprovação perante o $\mathrm{CADE}^{124}$, conforme disciplina do artigo 54 da Lei 8.884/94. Só este procedimento constitui condição da legitimidade do ato, cuja negligência acarreta aos infratores pesadas multas e processos administrativos.

O pedido que visa a aprovação deve ser realizado no prazo de quinze dias da sua consumação, sob pena de pesadas multas.

\footnotetext{
${ }^{118} \mathrm{FONSECA}$ J. J. B. da. Op. cit., p. 35. Sobre o fato de o interesse do consumidor justificar a concentração, ver MELEDO-BRAAND, Daniele. A consideração dos interesses do consumidor e o direito da concorrếncia, entre outros ao longo deste trabalho citados.

${ }_{119}$ Dramática, segundo VAZ. VAZ, I. Op. cit., p. 224-225.

${ }^{12 t}$ Idem, p. 226.

${ }^{122}$ Idem, p. 220.

122 Segundo LEÃES, tais fenômenos implicam "num conjunto de atos jurídicos, resolvendo-se, como diz a lei, numa operação, vale dizer, num procedimento negociał". LEÃES, L. G. P. de B. Op. cit., p. 88. ${ }^{123}$ VAZ, I. Op. cit., p. 227.

${ }^{24}$ Através do conhecido dever de notificar - ou em alemão - anmeldepflicht. FONSECA, J. J. B. da. Op. cit., p. 30. Contudo, "A lei brasileira não utilizou cláusula gexal semelhante à da lei alemã, preferindo a técnica francesa de submeter os atos, sob qualquer forma manifestados, à apreciação do Consellio Administrativo de Defesa da Concorrência - CADE". Idem, p. 27.
} 
O CADE não poderá impugnar atos que demonstrem sua necessidade por motivos preponderantes da economia nacional e do bem comum e ausência de prejuízo ao consumidor ou usuátio final, independentemente de se estimulem a concorrência ou não ${ }^{125}$.

A tarefa se torna dificil quando se almeja conciliar a efetividade da defesa do consumidor com a tendência mundial de formação e fortalecimento de megaempresas, pois com a entrada em vigor da Constituição Federal de 1988 tanto a livre concorrência quanto a defesa do consumidor adquiritam status de princípios constitucionais a serem respeitados, pois são normas de igual valor hierárquico ${ }^{126}$. Impõe-se um chamado balanceamento econômico ${ }^{127}$, uma compatibilização para a soluçáo dos conflitos entre os princípios.

Evidenciando, vê-se que uma das primeiras preocupações das autoridades ao analisarem uma concentração de empresas consiste na busca de mecanismos capazes de salvaguardar os direitos do consumidor ${ }^{128}$. Também um ato pode ser aprovado pela evidência que vá beneficiar o consunidor ou the reserve uma parte razoável do lucro resultante, o que é, pata alguns autores europeus, o objetivo final e o critério de aplicação do direito de concorrência ${ }^{129}$.

Devido a isso, há autores que vêem o CADE também como um órgão de defesa do consumidor ${ }^{\sharp 30}$, pois a lesão de um consumidor pode ser a evidência de uma prática abusiva, cujos efeitos gerais (ou universais) sobre o mercado denotam o abuso de posição dominante ${ }^{131}$. LOPES, por exemplo, afirma que o consumidor é o centro do direito da concortência, já que sua proteção permeia toda a discussão deste direito ${ }^{132}$. Já segundo Danièle MELEDO-BRIAND, se se considerar efetivamente que a satisfação dos consumidores é a finalidade última da atividade econômica, e o consumidor enquanto destinatário final das regras de mercado como elemento da dinâmica de mercado, poderá se conciujr que o direito da concorrência serve igualmente aos interesses dos consumidores ${ }^{133}$.

Ainda, a lesão pode ser o ponto de partida de uma investigação que pretenda verificar se determinado mercado é ou não concorrêncial. Assim é que o consumidor vai obter a manutenção de um ambiente que se actedita possa vir a ser-lhe favorável, por garantir eficiência alocativa e produtiva, preços mais baixos, produtos mais abundantes e alternativas.

\footnotetext{
${ }^{125}$ MAGNLHĀES, y. C. de; SAMPAIO, O. C. de A. Op. cit., p. 35. Se o Brasil tivesse adotado a teoria da concoryencia potencial, diferente seria este último entendimento.

${ }^{126} \mathrm{VAZ}, 1$. Op. cit., p. 223.

${ }^{127}$ MELEDDO-BRIAND, D. Op. cit., p. 44.

i2A VAZ, 1. Op. cit., p. 220 e 231.

:29 Como em MELEDO-BRIAND, D. Op. cit., p. 41 e seguintes.

${ }^{130}$ Como em LOPES, J. R. de l. Op. cit., p. 80.

${ }^{131}$ Idem, p. 82.

${ }^{132}$ Idem, p. 86.

1,3 MELEDO BRIAND, D. Op. cit., p. 41.
} 
Vale esclarecer que o interesse do consumidor individualmente considerado não é o objeto de decisão do Conselho ${ }^{134}$, mas deve ser pleiteado perante o judiciário civel ou criminal. Isto é, em todos os casos levados àquela instância o interesse do consumidor ou o progresso econômico deve dizer respeito ao conjunto da coletividade $e^{1.35}$.

Robert BORK, um americano considerado o mais reducionista, por sua vez, é.mais explícito ao afirmar que o único parâmetro válido para autorizar a concentração é o bem-estar do consumidor ${ }^{136}$.

Igualmente em direito compatado, no Reino Unido observa-se que a preocupação com o consumidor integra o direito da concorrência e foi reforçada pelo The consumer Act de $1974^{137}$. Já no direito francês os dois regramentos perseguem paralelamente os seus objetivos $^{138}$, havendo várias disposiçōes legais interconectadas.

Por derradeiro, já em encaminhamentos finais deste paralelisno enrre o interesse dos consumidores e a reorganização de empresas, é devida menção ao instrumento do compromisso de desempenho, que tem se constituído numa das principais garantias de defesa do consumidor ${ }^{139}$ e da concortência. Em verdade, éo principal mecanismo de defesa dos consumidores que pode ser acionado e funcionar de modo eficiente, disciplinado no artigo 58 da Lei $8.884 / 94$. Há, todavia, outros mecanismos postos à disposição da socicdade como meio de defesa das prerrogativas dos usuários e consumidores de bens e serviços. Mas este exige que os beneficios decorrentes da transação sejam distribuídos eqüitativamente entre as empresas e os consumidores finais.

Dele deve constar a descrição das metas quantitativas e qualitativas a serem atingidas em prazos pré-definidos e as formas de fiscalização do seu cumprimento, cábendo ao consurnidor uma parte da tarefa de acompanhar e fiscalizar se as promessas foram realizadas ${ }^{140}$.

Ourras limitações à reorganização de empresas que não a Lei da Concorrência nern o interesse do consumidor podem ser encontradas no direito do rrabalho brasileiro. Lá, a responsabilidade do grupo de sociedades, enquanto unidade econômica, em face do contrato de trabalho, que é solidária ${ }^{i 41}$, promove temor em empresários e é ponderada como fator negativo na análise das conveniências de se promover a reorganização.

Na parte ora encerrada foram repassados os principais fatores motivadores que levam as empresas a se submeterem a processos de fusão ou cisão, bem como os desejados resultados buscados, sejam redução de custos ou conquistas de novos clientes.

\footnotetext{
${ }^{134}$ LOPYS, J. R. de L. Op. cit., p. 82 e 86.

${ }^{135}$ MELEDO-BRIAND, D. Op. cit., p. 57.

${ }^{136}$ Citado em FONSECA, J. J. B. da. Op. cit., p. 28.

${ }^{137}$ MELEDO-BRIAND, D. Op. cit., p. 40.

${ }^{139}$ Idem, ibidem.

${ }^{139} \mathrm{VAZ}, \mathrm{I}$. Op. cit., p. 227 e $228-230$.

${ }^{140} \mathrm{Idem}$, p. 229-230.

${ }^{141}$ COUTO e SILVA, C. V. do. Op. cit., p. 22.
} 
Dentre os tipos aptesentados o de concentração horizontal é o mais corriqueiramente utilizado, mormente pelo fato de que a empresa procura outra que tenha interesses, atividade e participação no mercado compatíveis com a sua, mesmo que seja concorrente direta.

$\mathrm{Na}$ seqüência foi dimensionado o peso do interesse do consumidor na eventual aprovação ou não de uma concentração ou desconcentração empresarial, tendo sido afirmado que, segundo autores ali indicados, o benefício ao consumidor é o objetivo final do direito da concorrência, regulador dos processos aqui analisados, cujas formas e fases de manifestaçâo serão tratadas a seguir.

Ainda, foi visto como enfrentar a afetação que o fenômeno concentracionista promove na concorrência de mercado estabelecida ou a se estabelecer. Para tanto retratou-se a figura do instrumento do compromisso de desempenho. Este é mais um elemento que evidencia a relação interna próxima que têm o direito do consumidor com o direito da concorrência na relação de ambos com as compenetrações.

Por fim, observou-se que a responsabilidade do grupo de sociedades a ser formado com a concentração, que é solidária, exerce um certo receio nos empresários com o ímpeto concentracionista.

Em seguimento, aquela que é a parte final do trabalho indicará as formas e fases especificas de concentração e desconcentração adimitidas pelo novo Código Civil brasileiro, além de aspectos atinentes a estes processos.

\section{B. Formas e fases de compenetração}

Há vátias técnicas de reorganização empresarial, servindo algumas à concentração e outras à desconcentração societária, como no caso da cisão. Em todas elas cada empresa-parte abre mão de uma parcela de sua autonomia para, juntas, realizarem um empreendimento comum.

Na Europa continental, sobretudo na Itália, a fusão é gêneto e a incorpotação (fusão imprópria) é espécie. Assim a diferença está que na primeira a dissolução abrangerá todas as sociedades, e na segunda todas, menos uma, segundo ensina BULGARELLI, em obra densa, consistente, coerente e que esgota $o$ assunto ${ }^{142}$.

Mas no ordenamento pátrio são figuras distintas, perfeitamente identificáveis, por fehz iniciativa para se evitar confusões, tendo permitido o legislador, com clareza c precisão, serem usados os termos de fusão e incorporação.

${ }^{142}$ BULGARELLI, W. Fusões, incorporações e cisóes de sociedades, 
As associações normalmente são negociadas sob o maior sigilo, geralmente entre duas empresas, e apenas anunciadas quando elas são encerradas, momento em que se dá a assinatura de instrumentos que assegurem o cumprimento dos ajustes ${ }^{143}$.

Em que pese essas compenetrações estejam reguladas pela Lei das Sociedades de Capital (ou, impropriamente, das Anônimas) por uma questão de sedes materiae, e não pelo Código Comercial, tais fenômenos são destinados a qualquer espécie de ambiente empresarial, até mesmo uma firma individual. Claro que a maior intensidade da incidência do fenômeno se dá nas anônimas, consideradas a configuração ideal da macroempresa.

Não são poucas as vezes que a própria lei do anonimato se refere expressamente à específica autorização do estatuto ou do contrato social, este instrumento típico das sociedades de pessoas, e também às reuniões entre órgãos de administração ou sócios-gerentes, o que deixa a entender que as referidas operações poderão ptocessar-se entre sociedades do mesmo tipo ou de tipos diferentes ${ }^{144}$.

Tendo isto sido visto, de imediato se passa a analisar algumas formas mais importantes e outras menos importantes, conforme são mais ou menos requeridas pelas empresas. Vale lembrar que este regramento nunca fez parte do ordenamento civil nem do Código Comercial brasileiro. Já o novo Código Civil disciplinou, em regras gerais, com remissões à Lei das Sociedades Anônimas, o assunto.

A primeira das formas de compenetração a ser apresentada é a transformação. Ocorre quando a sociedade passa de uma espécic a outra, como que numa metamorfose ${ }^{145}$, independentemente de dissolução ou liquidação ${ }^{146}$. Tal ato depende do consentimento de todos os sócios, salvo se prevista anteriormente no contrato ${ }^{147}$. Neste tipo não se verifica a extrnção da sociedade e nem há prejuizo ou modificação do direito dos credores ${ }^{148}$.

Também não ocorre a sucessão de sociedades ${ }^{149}$. Portanto, os bens que constituem o patrimônio social não serão objeto de transmissão ${ }^{150}$.

Sobre a transformação vale esclarecer que mero aumento ou redução do capital, retirada de herdeiros e espaçamento da duração da sociedade não importa em transformação $0^{151}$.

\footnotetext{
143. MAGALHÃES, J. C. de; SAMPAIO, O. C. de A. Op. cit., p. 38.

${ }^{t 4}$ BORBA, José Edwaldo Tavares. Direito societário, p. 415 e MENDONCA, José Xavier Carvalho de. Tratado de direito comercial brasileiro, p. 81.

i45 BORBA, J. E. T. Op. cit., p. 414.

${ }^{146}$ Artigo 1.113 do novo Código Civil.

${ }^{147}$ Artigo 1.114 do novo Código Civil.

${ }^{148}$ Artigo 1.115 do novo Código Civil.

${ }^{145}$ BORBA, J. F. T. Op. cit., p. 414

${ }^{150} \mathrm{Na}$ Lei $6.404 / 76$ a disciplina da transformaçâo se encontra expressa no artigo 220.

${ }^{15 t}$ MENDONÇA, J. X. C. de. Op. cit., p. 76.
} 
Se a transformação for autorizada pelo contrato social, ela é considerada pura e se confunde com a alteração contratual. Se, contudo, não for autorizada pelo contrato primordial, essa modificação é constitutiva ${ }^{152}$ e se confunde com a criação de uma nova sociedade por contrato social também.

A segunda das mais importantes é a fusão. A fusão é a união de duas ou mais sociedades que se extinguem dando lugar à criação de uma nova, que as sucede em todos os direitos e obrigações ${ }^{153}$. Trata-se da forma mais radical e menos perigosa de concentração. Exige uma primeira fase de aprovação nas assembléias-gerais de cada uma das sociedades incluídas na operação, com o fito de aprovar o protocolo e nomear os peritos que avaliarão os patrimônios das outras companhias ${ }^{154}$. Teoricamente as sociedades não entram em liquidação, mas desaparecem em absoluto. Isso tepresenta substancial economia financeira.

As sociedades anônimas são as que se apresentam mais adaptadas a sofrer processo de fusão, mas isso não impede que outras formas se submetam a esse processo. Não há dissolução daquelas, todavia.

A fusão pode resultar em sociedade de pessoas, na qual a responsabilidade dos sócios seja maior que nas anteriores anônimas fundidas. Isso pode ensejar direito de recesso, pelo aumento da responsabilidade social, assunto que será visto oportunamente.

A incorporação é a operação pela qual uma ou mais sociedades são absorvidas por outra, que thes sucede em todos os direitos e obrigações ${ }^{155}$. Os acionistas da sociedade incorporada recebem, em troca de suas antigas ações que se extinguem, ações do capital da incorporadora. Exige-se assim, simplesmente novo contrato social. Nesta operação desaparece uma ou mais sociedades, chamadas incorporadas, e permanece a sociedade incorporadora, sem qualquer alteração na sua pessoa juridica, mas sucedendo às incorporadas em seus direitos e obrigações. Por fim, é ônus da incotporadora declarar extinta a incorporada ${ }^{156}$.

Vale ressaltar que o artigo 264 da Lei 6.404/76 fala da incorporação e fusão de sociedades já controladas, diferenciandomse dos demais casos getais, onde as sociedades são independentes. Isto é assim pois aqui não há duas maiorias acionárias distintas aprovando a operação, apenas o grupo acionário da controladora, que também atua na controlada, votando de igual mancira e impedindo o contraponto. Tal procedimento ocasiona o risco de a operação da controladora resvalar pata um contrato consigo mesmo! Este procedimento tem norma especial na lei, exigindo critério de avaliação dos patrimônios líquidos das

\footnotetext{
${ }_{1.52}$ Idem, p. 77.

153 Na Lei $6.404 / 76$ a disciplina da fusão se encontra expressa no artigo 228. E no novo Código Civil no artigo 1.119.

35. Segundo o artigo 1.120 do novo Código Civil.

${ }^{155} \mathrm{Na}$ Lei $6.404 / 76$ a disciplina da incorporaçào se encontra expressa no artigo 227. E no novo Código Civil no artigo 1.116 .

36 Artigo 1.118 do novo Código Civil.
} 
sociedades participantes determinados e relação de troca de ações fixada, pois passa pelo que os alemães chamam de Aquivalenz störung, ou turbação da equivalência ${ }^{157}$.

Já a cisão, diversamente dos anteriores fenômenos de aglutinação, opera por cissiparidade ${ }^{158}$. É uma modalidade muito utilizada por permitir que se dê um novo destino a um conjunto de bens pertencentes a uma determinada empresa em vias de recomposição acionária ou se divida uma sociedade em várias unidades autônomas.

Neste caso muito se discute a solidariedade da sociedade primitiva e das que absorvem

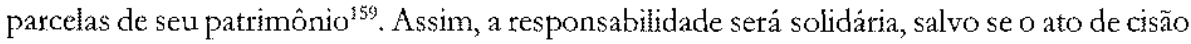
determinar o contrário. Cuidado. Essa regra é mais um instrumento de lesão aos credores que não estiverem atentos à divulgação da cisão, conforme $\mathrm{BORBA}^{16 \hat{4}}$, pois seus créditos passarão a ser garantidos apenas por uma parte do antigo patrimônio.

Arnoldo WALD tem um artigo específico sobre esta responsabilidade que trata de notifícação, isto é, da fotma pela qual a solidariedade haveria de ser resguardada, no interesse dos credores, o que é matéria relacionada ao artigo 233 da lei societária. Portanto, para que a solidariedade seja mantida, é necessário que os credores notifiquem a sociedade cindida (ou decorrente de cisão) para que se mantenha o vínculo de solidariedade entre os dois devedores ou responsáveis que substituem o responsável anterior ${ }^{161}$, usando simples notificação, não necessitando ser a qualificada, judicial| ${ }^{162}$.

Vale atentar que nos demais casos que não se referem à cisão, que são a incorporação e a fusão, o credor tem a faculdade de pleitear judicialmente a anulaçã̃o da operação.

Se a cisão for total, há a extinção da companhia cindida. Se for parcial, há a divisão do capital.

Por fim, como última característica considerada importante sobre esta forma de teorganização empresarial, Nelson $A B R A \tilde{O}$ adverte que a cisão de sociedades empresátias só é possivel quando a matriz for uma anônima, citado por Luiz Antonio Soares HENTZ ${ }^{163}$.

\footnotetext{
${ }^{157}$ LEAES, L. G. P. de B. Op. cit, p. 93.

158 BORBA, J. E. T. Op. cit., P. 423.

159 Sobre o assunto há oriundo do Supremo Tribunal de Justiça o agravo reginental númeto 22.307/RJ, de 14 de setembro de 1992, num agravo de instrumento, cuja ementa é "Fusão de empresas de ônibus, pela quitaçäo, por uma délas, de praticamente $100 \%$ das cotas da outra. Responsabilidade da adquirente por acidente causado no período en que perdurou a fusão. Agravo regimental não provido".

${ }^{160}$ BORBA, J. E. T. Op. cit., p. 425.

${ }^{16}$ WALD, Arnoldo. Da responsabilidade solidária na cisão e da notificação às empresas devedoras, p. 53.

iri Idem, p. 56.

${ }^{16,3}$ HENTZ, L. A. S. Direito comercial atual: de acordo com a teoria da empresa, p. 158.
} 
Fugindo dos modelos clássicos, embora alguns autores a tenham como um termogênero de todas as formas anteriormente abordadas, vem a apresentar-se a joint venture, que é uma associação entre empresas em busca de canais de distribuição, importantes para a expansão dos negócios ${ }^{164}$. É associação para um determinado empreendimento metcantil ou industrial, por cujos investimentos se obrigam e ou de cujos resultados fruem os seus participantes, dentro do plano assentado em contrato para a formação de sociedade.

Este tipo muito comum de associação torna imprescindível haver mútua colaboração ${ }^{165}$, pois ele não apresenta estabilidade nem permanência ${ }^{i 66}$. Visa a objetivos específicos limitados, podendo até mesmo ser criada exclusivamente para uma operação determinada ${ }^{167}$. Pode ser doméstica ou internacional, tendo se mostrado um atraente meio de empresas de pequeno, médio e grande se inseritem no mercado tegional ${ }^{168}$ e internacional.

Outras formas de compenetrações empresariais que muitas vezes passam desapercebidas são a subsidiária integral, a sociedade de economia mista, o firmamento de um acordo de acionista, o contrato de distribuição ${ }^{169}$, a tetceirização, as sociedades coligadas, os grupos de sociedades em geral e os consórcios de empresas.

Terceirização, por exemplo, é a transferência da gestão de parte das atividades de uma empresa para terceiros ${ }^{170}$. Sociedades coligadas são aquelas em que uma participa no capital da outra, com dez por cento ou mais, sem, contudo controlá-la. Já os grupos de sociedades são regulados pelo artigo 265 da Lei $6.404 / 76$, podendo ser constituídos pela sociedade controladora e suas conrroladas ${ }^{171}$. São formados por companhias que, embora mantendo integras suas personalidades juridicas e patrimônios próprios, associam-se para atuar em conjunto visando um fim comum. Tal deve ser aprovado em assembléia geral extraordinária, com quorum qualificado. Dali sai uma convenção que obriga a combinação de tecursos e esforços para a tealização de objetivos. A sociedade controladora comanda o grupo, exercendo o controle das sociedades filiadas.

\footnotetext{
${ }^{164}$ MORAES, Amanda Gama. Contratos internacionais, joint ventures e tipos de joint ventures, p. 212 e 226 e CARVALHO, P. Op. cit., p. 163.

${ }^{165}$ REALE, M. Op. cit., p. 90.

${ }^{166}$ BLLLGARELLI, W. O direito dos grupos e a concentração de empresas, p. 70.

i67 Idem, ibidem.

:68 CARVALHO, P. Op. cit., P. 165.

${ }^{169}$ Ver para $O$ assunto a obra FARIA, Werter R. Direito da Concorrência e Contrato de Dístríbuição.

${ }^{170}$ Trata-se de espécie de cooperação empresarial sucedida desde os anos 70 , quando começou com as áreas de recepçäo, segurança e limpeza. CARVAlHO, P. Op. cit., p. 164.

${ }^{171}$ REALE, M. Op. cit., p. 86.
} 
Por fim, os consórcios, que estão disciplinados nos artigos 279 a 281 da Lei 6.404/76. Constituem-se em agrupamentos de companhias com a finalidade de executar determinado empreendimento. Não têm personalidade jurídica. As empresas consorciadas estão solidariamente responsáveis por quaisquer prejuízos a consumidores causados pelo consorciado gestor ${ }^{172}$.

Contudo, HENTZ entende difetente. Para o autor, as consorciadas respondem apenas pelas obrigações assumidas, sem presunção de solidariedade e a falência de uma não se estende às demais, continuando a existir o consórcio com as demais contratantes ${ }^{173}$.

Sobre todas as formas anteriormente vistas, alguns as consideram um casamento ${ }^{174}$, outros como uma aventura comum, uma parceria, uma cooperação, onde união e associação são termos que podem ser relacionados aos processos vistos. Em verdade, todas são combinações de capirais ou de técnicas para o desenvolvimento de projetos, getalmente complexos e dispendiosos, que geram efeitos jurídicos em mais de uma nação.

Uma vez indicadas as principais formas de compenetração de empresas, agora também fazendo parte do rol das disposições do novo Código Civil brasileiro, cabe tratar quais as fases $^{175}$ que as empresas devem vencer para a aprovação interna desses atos. Essas fases são o protocolo e a justificação, a assinatura propriamente dita do contrato, a oportunidade ao direito de recesso, o estabelecimento do valor do eventual reembolso e, de outra ordem, o exercício do direito de continuar sócio dos que resultam, em função das reorganizações, detentores de menos de uma ação.

Protocolo e justificação são instrumentos introduzidos pela Lei 6.404/76 que apresentam um apertadíssimo formalismo, segundo LEÃES $S^{176}$, onde estão disciplinados no artigo 224. Então o processo de compenerração começa com a elaboração de um protocolo firmado pelos órgãos de administração ou sócios-gerentes das sociedades, submetido após às assembléias ou reuniões de sócios. Este documento define as condições e bases da operação, as características das ações a serem atribuídas aos sócios das sociedades que se extinguirão e os critérios de aputação dos respectivos quantitativos, critério da avaliação dos patrimônios líquidos das sociedades envolvidas, se a preço de mercado ou mediante recurso aos valores contábeis ${ }^{177}$, o projero de estatuto, ou alterações estatutárias, o valor do capital das sociedades a serem criadas ou do aumento ou redução do capital das sociedades envolvidas na operação, a proporção de troca das ações e o critério utilizado para a relação de substituiçãa ${ }^{178}$.

\footnotetext{
17 Sobre os riscos dos consórcios, em especial a solidariedade por quaisquer prejuizos a consumidores e a desconsideraçăo sem levar em conta a confirmaçăo da fraude ou do abuso de direito, ver ROCHA, João Luiz Coelho da. Os consórcios de empresas e seus riscos jurídicos, p. 86.

${ }^{173}$ HEN'TZ, L. A. S. Op. cit, p. 160.

${ }^{174}$ CARVALHO, P. Op. cit., p. 167.

175 Segundo enumeração de LEÃES, L. G. P. de B. Op. cit., p. $90-91$.

${ }^{176}$ Idem, p. 88.

${ }^{177}$ Idem, p. 91.

${ }^{178}$ BORBA, j. E. T. Op. cit., p. 419.
} 
O protocolo não tem a natureza de pré-contrato, posto que não obriga a conclusão do negócio ${ }^{178}$, pois é procedimento preparatótio, segundo LEÃES ${ }^{180}$. Noutro sentido, tem-se uma posição, que é isolada, que o considera um verdadeiro contrato.

A segunda fase é a da justificação. À assembléia geral deverão ser fornecidos todos os esclarecimentos e as justificativas da operação, bem como as causas de eventuais modificações nos direitos dos acionistas preferenciais ${ }^{181}$ e as razões para as modificações destes.

Quando a incorporação é de controlada, a avaliação é obrigatoriamente a de preço de mercado. Nos demais casos pode ser também realizada a valores contábeis ${ }^{182}$.

A fusão e a cisão, assim como a incorporação da companhia em outra, exigem, na assembléia-getal que aprovar o protocolo ou justificação, maioria qualificada. Na incorporadora, basta maioria simples ${ }^{183}$.

Ainda, segundo o artigo 225, a fase da justificação trata-se de um verdadeiro direito de informação do acionista.

Após a deliberação das assembléias-gerais chega-se ao ponto culminante do negócio, o contrato ${ }^{184}$, onde os interesses se ajustam. Assim, quaisquer das formas antes vistas são baseadas em contratos, ao império dos quais devem credores e acionistas se curvarem.

Em verdade, podem ser tidos como conrratos sociais típicos. Na maioria dos casos são reformas de contratos sociais ou dos estatutos típicos, como prevêem os artigos 223, 135 e 136 da Lei das Sociedades Anônimas.

Não entendendo assim, no mínimo deve ter-se, como Patrícia CARVALHO, que os acordos são pontuais, sejan de licença de marcas, de fornecimento, de maquinátio, de knowhow, de transferência de tecnologia, de assistência técnica, de segredo, mas todos variam conforme o caso prático ${ }^{185}$.

Já para LEÃES, estas técnicas de reorganização não estão sujeitas a um simples contrato, mas cabe encará-las como um típico instituto societário que implica num conjunto de atos juridicos, resolvendo-se numna operação e num procedimento negocial, como rambém se manifesta a lei ${ }^{i 86}$.

\footnotetext{
${ }^{174}$ Idem, p. 420.

${ }_{180}$ Trata-se de documento que não se reveste de eficácia vinculatjva, a não ser após a aprovação das assembléias, concluindo-se o procedimento. LEÃES, L. G. P. de B. Op. cit., p. 90.

${ }^{18:}$ BORBA, J. E. T. Op. cit., p. 420.

${ }_{182}$ Idem, p. 419.

is3 Idem, P. 421.

:s4 Atenção para o fato de que França, Itália, Atemarha e Argentina denominam o Protocolo de Contrato de Fusão.

?R: CARVALLHO, P. Op. cit., p. 169-170.

${ }^{88 .}$ Novamente ver LEÃES. LEÃES, L. G. P. Je B. Op. cit., p. 88.
} 
As únicas referências que a doutrina traz é que os contratos devem ser precisos ${ }^{187}$, conter cláusulas essenciais para o melhor conhecimento das partes, estabelecer direitos e obrigações, a legislação a qual estará subordinado e o prazo de vigência.

Talvez o mais tormentoso assunto chama-se direito de recesso ${ }^{188}$. Trata-se de incorporação italiana de 1882 ao Código Comercial para proteger os acionistas minoritários. Para Vivante, o direito de retirada age como um freio e um remédio contra o poder ilimitado das assembléias de modificar o próprio estatuto ${ }^{189}$.

No Brasil o instituto sempre serviu como uma forma de proteção aos acionistas, proporcionando uma melhor segurança aos novos investidores do setor empresarial em expansão. Modesto Carvalhosa o define como a faculdade legal do acionista de retirar-se da companhia, mediante a reposição do valor patrimonial das ações respectivas ${ }^{190}$.

Ele reflete a tensão permanente entre os interesses individuais dos sócios e as necessidades de desenvolvimento da empresa, por situar-se no epicentro dos conflitos. Sobretudo, é o contrapeso ao poder incontrastável do acionista controlador.

Mas a evolução do diteito de recesso mostra uma curva parabólica de ascensão seguida de descenso, segundo COMPARATO ${ }^{19}$, como será visto, em função de modificações recentes na legislação brasileira, retratadora do referido direito. Inicialmente a Lei 6.404/76 havia disciplinado inúmeras hipóteses de recesso de acionistas, a maioria nos artigos 137, 221, 236, 252 e 256. Tratou-se de extensa gama de direitos e medidas em favor dos acionistas nãocontroladores, destacando-se, entre eles, os chamados direitos essenciais, intangiveis, fundamentais ou interrogáveis do artigo 109, que visavam conter os atos de abuso de poder por parte dos controladores ${ }^{192}$.

Dois eram os pressupostos para o exercício do direito: a) haver deliberação eficaz sobre uma das matérias que pernitem o direito de recesso; e b) não ter ocorrido o consentimento do acionista à alteração ${ }^{193}$. Mas vale ressaltar que no direito brasileiro não há recesso parcial; e mesmo os ausentes à assembléia poderão se valer da prertogativa de recesso.

\footnotetext{
${ }^{167}$ MORAES, A. G. Op. cit., p. 215 e 218.

${ }^{189}$ Sobre 0 assunto, dentre a bibliografia citada, ver BULGAREL.LI, W. O direito de recesso nas hipóteses de incorporação, fusão, cisão e participação em grupos de sociedades: exclusão acar retada pela Lei 7.958 de 20.12.89, COMPARATO, F. K. O novo direito de retirada do acionista nos casos de fusão e incorporação, EIZIRIK, Nelson. Notas sobre o direito de recesso na incorporação, fusão e cisão das companhias, EIZIRIK, N. Reforma das S.A. e direito de recesso, LUCCA, Newton de. O direito de recesso no direito brasileiro e na legislação comparada, MENEZES, Paulo Lucena de. A disciplina do direito de recesso no Projeto de Reforma da Lei das Sociedades Anônimas e MORITZ, Renata Brandào. As hipóreses de recesso na Lei das Sociedades Anônimas.

199 COMPARATO, F. K. Op. cit., p. 11.

${ }^{190}$ Citado por LUCCA, N. de. Op. cit, p. 13.

191 COMPARATO, F. K. Op. cit. p. 12.

192 BULGARELLI, W. Op. cit., p. 74 e LUCCA, N. de. Op. cit., p. 8.

193 Segundo classificação encontrada em MORYTZ, R. B. Op. cit., p. 56.
} 
O efeito negativo dessa libetdade é que caso o direito de recesso seja excessivamente exercido poderá ser nocivo à companhia e prejudicar a sua funcionalidade ${ }^{194}$. Ao prejudicial exercício, aquele que impossibilita as compenetrações societárias, se convencionou chamar abuso da minoria.

Isto posto, em 1989 a Lei Lobão número 7.958 suprimiu do artigo 137 da lei das Sociedades Anônimas os incisos VI (incorporação da companhia em outra, sua fusão ou cisão) e VIII (participação em grupo de sociedades) do artigo 136 e, em conseqüência, a possibilidade de direito de recesso em casos de incorporação, fusão ou cisão. Assim dispondo removeu eventuais obstáculos às compenetrações representados pelo direito de recesso. Contudo, devido a problemas de elaboração da lei e mesmo cochilo e despreparo do legislador, segundo alguns doutrinadores e algumas decisões da Comissão de Valores Mobiliários $(\mathrm{CVM})$, manteve este direito potestativo dos acionistas noutros cinco artigos, como no 230 e no 270 , o que causou enorme confusão entre juristas e acionistas das sociedades, em conseqüência ocasionando inúmeros litígios judiciais.

A Lei Lobão, causadora de inúmeras discórdias, e que à época havia servido ao interesse de uma única companhia de grande porte desejosa de ver incorporada uma controlada sua sem que fosse eventualmente molestada pelo recesso dos minoritários, assim foi de um casuísmo vergonhoso que grassou a ordenação jurídica brasileira. Segundo LUCCA, de catáter grotescamente casuístico, triste episódio legislativo, ela se constituiu num verdadeiro estelionato legislativo e totalmente ine fica $z^{195}$.

O principal problema ocorreu porque parte da doutrina entendeu que a manutenção da possibilidade de recesso nos demais artigos da lei manteve intocada essa faculdade ao acionista. A lei suscitou as mais variadas criticas e por muito tempo, até ser revogada, bavia dúvidas se ela tinha ou não suprimido o referido direito.

BULGARELLI, contudo, em longa interpretação sistemática que fez posicionar-se radicalmente diferente ao acima exposto, utilizando-se da teoria da hermenêutica ou da interpretação, entendeu que tendo a lei Lobão suprimido as hipóteses do artigo 137, todas as demais que foram esquecidas de ser suprimidas, mesmo assim estariam revogadas. Dizo autor que a lei derrogou o direito de retirada dos acionistas dissidentes, eliminando as possibilidades de abuso de posição minoritária que impediam compenetrações ${ }^{196}$, o que era mesmo o desejo implícito.

\footnotetext{
${ }^{194}$ BULGARELLI, W. Op. cit., p. 72.

${ }^{195}$ LUCCA, N. de. Op. cit., p. 22-23.

196 BULGARELLI, W. Op. cit., p. 78-79.
} 
Mas não obstante entendimentos como este a pendenga continuou ${ }^{197}$. Fato é que em 1995 a Medida Provisória número 1.179 de 3 de novembro de 1995 mostrou que se a Lei Lobão tivesse realmente restringido tal direito, não haveria porquê o Governo Federal se preocupar em novamente restringir as tnesmas hipóteses de direito de recesso ${ }^{198}$, na tentativa de evitar demandas dos minoritários nos seus processos de privatização.

Voltando um pouco no tempo, a legislação norte-americana de 1969 excetuou do direito de recesso as ações largamente negociadas no mercado, aplicando essa regra da Lei de Delaware inicialmente a noventa por cento das empresas de lá $^{199}$.

Esse exemplo serviu ao interesse do Governo brasileiro, envolvido em processo de privatização e reforma administrativa, pois com semelhanre técnica impeditia o uso, por parte dos acionistas trinoritários de suas empresas, do direito de recesso, não sendo possível, então, eles obstaculizarem facilmente os processos de reestruturação societárias do programa de privatização. Ocorre que o exercício de ral direito entravaria a reorganização pelo fato de a empresa não ter como ressarcir todos os retirantes com base no valor patrimonial da ação, sempre muito superior ao valor econômico ou de mercado.

Então nova Lei númeto 9.457/97 estabeleceu algumas restrições ao direito de recesso nos casos de incorporação e fusão e eliminou a hipótese nos casos de cisão. A lei 9.457/97 reproduziu o exemplo americano e também entendeu que quando a ação for facilmente negociável no mercado não cabe direiro de recesso ao seu detentor, diminuindo, assim, se não neutralizando, as hipóteses de recesso para os acionistas dissidenres. Presume-se que em tais hipóteses o acionista insatisfeito possa alienar suas ações no mercado, descahendo o direito de recesso peranre a companhia, que, vale lembrar, seria exercido segundo o valor patrimonial e agora o é pelo valor de mercado.

Esta legislação, pelo artigo $6^{\circ}$, revogou expressamente a confusa, desastrada e malfadada ${ }^{200}$ Lei Lobão. E também suprimiu o direito de recesso nos casos de cisão. Assim atendeu diretamente aos objetivos governamentais de reduzir os custos dos processos de privatização de concessionárias de telecomunicações e de energia, nos quais as cisões seriam utilizadas como ajustes prévios à alienação do controle das empresas. Para alguns críticos, refletiu o tatcherismo tropical ${ }^{2 / 11}$ e uma política govennamental neoliberal a serviço das macropolíticas do momento.

\footnotetext{
197 Vale referir a ementa do recurso especial número $68.367 / \mathrm{MG}$, de 10 de dezembro de 1998 , que manifesta a "Subsistência do direito mesmo após a vigência da Lei $7.958 / 89$ que, modificando o disposto no artigo 137 da Lei $6.404 / 76$, absteve-se, entretanto, de alterat o contido no artigo 230 , 'caput' da mesma Lei que também regulava o direito de retirada". Ver ainda as correntes neste e noutro sentido em MORITZ, R. B. Op. cit., p. 68 e seguintes, en EYZYRJK, N. Op. cit., p. 75 e em LUCCA, N. de. Op. cit., p. 24-25.

${ }_{1 \% 8}$ Conforme observou MORITZ, R. B. Op. cit., p. 72.

COMPARATO, F. K. Op. cit, p. 12 e LUCCA, N. de. Op. cit., p. 20.

${ }^{200}$ Críticas feitas em LUCCA. Idem, p. 22-27.

${ }^{201}$ Idem, p. 30.
} 
Em ideal final, objetivou a Lei eliminar a indústria do recesso, isto é, aquele procedimento eticamente condenável, formada por acionistas que compravam ações como específico objetivo de exercer o direito de recesso pelo valor patrimonial das ações, com relação a decisões empresariais já divulgadas pela administração das companhias.

Conceitualmente, a indústria do recesso pode ser tida como a operação de aquisição de ações de empresas que manifestaram desejo de se reorganizarem socialmente, realizadas com a única finalidade de dissentir de deliberações sociais e receber o reembolso das ações pelo valor patrimonial líquido, sempte mais alto que o de mercado ${ }^{202}$.

Fica claro o desejo de se reduzir o exercício desse direito de recesso, pois muitas vezes o minoritário prejudica a realização de operações a serem feitas pela companhia, discordando e querendo se tetirar dela. Isso não seria problema se essa retirada não representasse uma perda patrimonial grande para a sociedade, exigindo que a compankia desistisse da operação e retrocedesse em sua decisão sob pena de sucumbir.

A argumentação de que os minoritários muitas vezes abusam desta proteção legal, prejudicando operações que beneficiariam a sociedade, não é de todo exagerada e pode ocorrer de fato, como quer MORITZ ${ }^{213}$. Enntão, agora, somente terá direito de recesso nos casos de incorporação, fusão e participação de grupo de sociedades, o titular de ações que não sejam facilmente negociáveis no metcado aberto de capitais, isto é, daqueles tipos de ações que não apresentem a liquidez do IBOVESPA, daquelas espécies ou classes prejudicadas, e o titular das que não sejam emitidas por companhias nas quais mais da metade do total das ações emitidas encontrem-se em circulação no mercado, isto é, quando a conæpanhia não apresente expressivo índice de dispersão de suas ações no mercado ${ }^{234}$.

A lei 9.457/97 também não fez mais do que explicitar um direito já existente, ao acrescentar um parágrafo $3^{\circ}$ ao artigo 223 da Lei $6.404 / 76$, estabelecendo que nas incorporações, fusões e cisões que envolvam companhias abertas, as sucessotas também deverão ser companhias abettas ${ }^{205}$. O objetivo da norma é o de assegurar aos acionistas minoritários a manutenção das mesmas condições mais favoráveis de liquidez das ações (de companhias abertas) das quais eram titulates antes da operação $21 k$. Do contrário há uma nova hipótese de direito de recesso, mesmo para o caso de cisão, conforme o parágrafo $4^{\circ}$ do referido artigo.

\footnotetext{
${ }^{242}$ Seyundo o recurso especial número $197.329 /$ SP, "Não merece esta proteção o simples propósito de auferir lucros injustificados como se verifica com a aquisição das ações após a convocação da assembléia que objetiva introduzir as modificaçōes estatutárias de que pode resultar o direjto de retirada". Ver também EIZYRIK, N. Op. cit., p. B1.

${ }^{203}$ MORITZ, R. B. Op. cit., p. 75.

204 EIZIRIK, N. Op. cit., p. 76.

${ }^{205}$ BORBA, José Edwaldo Tavares. Direito societário, p. 417.

${ }^{209}$ EIZIRLK, N. Op, cit., p. 128.
} 
Já acionistas de companhia incorporadora não têm direito de recesso, pois não há que se supor que a incorporação de uma empresa vá lhes trazer prejuízo, conforme MORITZ, entre outros, que pensam que os acionistas não são prejudicados em seus interesses, pois tais operações representam um aumento no patrimônio da empresa que absorve a parcela da sociedade cindida, não havendo prejuizo para a receptora ${ }^{207}$.

Vale tessaltar que o artigo 264 fala da incorporação e fusão de sociedades já controladas, diferenciando-se dos demais casos gerais, onde as sociedades são independentes. Aqui não há duas maiorias acionárias distintas aprovando a operação, apenas o grupo acionário da controladora, que também atua na controlada, como já estudado. Segundo MORITZ, o direito de retirada será permitido aos acionistas da controlada discordantes da operação quando as telações de substituição das ações dos acionistas controladores forem menos vantajosas que as tesultantes $\mathrm{d} a$ avaliação do patrimônio liquido das duas sociedades, a preço de mercado. Portanto, a lei só permite o exercício do direito de recesso aos acionistas da controlada. Aliás, o raciocínio aquí é o mesmo utilizado nas incorporações de sociedades independentes, onde não se permite o direito de retirada aos acionistas das incorporadoras porque a operação resulta em aumento do capital da companhia e, portanto, benefícios para todos. Não há prejuízo para a sociedade controladora e para seus acionistas nesta operação, portanto não há que se falar emo direito de retirada $a^{208}$ para eles, assevera a autora ${ }^{209}$.

Após esta longa e conturbada evolução do direito de recesso no Brasil restam ser tratados o valor do reembolso e o inusitado exercício do direito de continuar sócio. Aquele assunto está presente no artigo 45 de Lei das Anônimas. Ali diz que reembolso é a operação pela qual a companhia paga aos acionistas dissidentes de deliberação da assembléia-geral o valor de suas ações. Este valor é baseado em laudo de avaliação consistente, emitido por três peritos ou por empresa especializada, necessariamente independentes da companhia, no prazo de 30 dias a contar da data da publicação da ata da assembléia-geral. Também estabeleceu critérios para o reembolso do acionista dissidente ${ }^{211}$.

\footnotetext{
${ }^{2013}$ MORYTZ, R. B. Op. cit., p. 61.

23:3 Ver, sobre tudo isso, o recurso extraordinário número $104.895 / \mathrm{RS}$, de 17 de junho de 1986, segundo o qual a lei não exige a mudança de objeto da empresa para o direito de recesso, bastando que o interesse dos minoritários seja prejudicado. Ainda, o recurso especial número $31.515 / \mathrm{SP}$, de 25 de março de 1996 , segundo o qual mera criação de novo tipo de açōes näo gera dircito de recesso, necessitando haver prejuízo ao sócio dissidente.

${ }^{2139}$ MORITZ, R. B. Op. cit., p. 65.

2i) Ver o recurso especial número 51.655 /RS, de 3 de dezembro de 1996, sobre o dissidente não ser obrigado a aceitar a oferta da maioria.
} 
Por fim, SQUASSONI observa o direito dos acionistas de continuarem sócios de sociedades em função das reorganizações. Segundo o autor, certas companhias têm um número bastante elevado de acionistas minoritátios detendo, cada um, uma participação muito pequena no capital social. Neste caso, pode ocorrer que certos acionistas resultem na condição de detentores de menos de uma ação. Vale lembrar que esta, bem como o voto assemblear, são indivisíveis. Mesmo assim, para o autor, tal fato não dá ao acionista o direito de inviabilizar a operação, pois a plena restituição the é assegurada e sua tetirada não constitui dano patrimonial ${ }^{211}$.

Ainda, a lei $6.404 / 76$ não estabelece entre os direitos essenciais do acionista o direito de continuar sócio, e por tal não pode ser invocado para fins de anular a decisão de uma assembléia-geral que delibera por uma reestruturação societária onde fique garantido o seu direito à restituição, com a empresa recomprando as frações para cancelamento.

Por fazerem parte do rol das disposições do novo Código Civil brasileiro, no tópico que finda foram indicadas as principais formas de compenetração de empresas e as particularidades de cada uma delas. Igualmente, viu-se as fases que as empresas devem cumptir para tal objetivo, e foi retratada a grande conturbação da questão do direito de recesso que costuma criar problemas àquele propósito.

\section{CONSIDERAÇÕES FINAIS}

No presente trabalho ohservou-se a relevância e primazia mundial dos estudos do jurista Augusto Teixeira de Freitas quanto à unificação das obrigações civis e comerciais em um único documento de direito privado, o que já era sua idéia em 1854. Mas o Código Comercial brasileiro surgiu antes, regulando matéria civil e mesmo invadindo esta esfera. Um Código Civil, por sua vez, sem a mesma sorte, ao Brasil veio em 1916, e mesmo assim não consagtou a idéia de unificação das obrigações, ainda que ante aos exemplos de outros países.

Um documento como este agora é realidade, tendo transcendido a unificação das obrigações, assim consagrando outras anteriores tentativas. Incluiu uma parte do direito empresarial imediatamente após àquela, de denominação direito empresarial, em substituição a de direito comercial. Esta nova parte incluída determinou uma nova orientação ao fenômeno da reorganização de empresas sediadas em território nacional. Assim, tal se encontra agora no novo Código Civil brasileiro, que por sua vez traz remissões a outras leis especiais sobre a matéria. Muitos outros assuntos foram tratados, como questões relativas ao registro, nome, prepostos e exigibilidade e dispensa de escrituração, e muitos conceitos tedefinidos, em especial o de empresa, à luz da teoria da empresa, pelo Código adorada.

${ }^{211}$ SQUASSONI, C. M. F. Op. cit., p. 144. 
Vale afirmar que ou o novo Código deveria trazer toda a legislação esparsa pata dentro de si ou nada. Trazendo toda, corria o risco de igualar-se ao de cinco milheiros de Teixeira de Freitas, inviabilizando-se. Trazendo nada, mantinha integralmente a disciplina dos assuntos nas leis esparsas especiais e afastava a discussão sobre a autonomia do direito comercial: Poderia ainda ter reunido apenas os assuntos não tratados por nenhuma lei, especialmente os que seguem inexistindo, como a questão da Empresa Individual de Responsabilidade Limitada, hipótese considerada a melhor.

Com a unificação, a distinção petderá muito da sua importância. Mas é mantida a autonomia do direito comercial, mesmo didática e científica, perante o direito civil, em que pese o desaparecimento da parte mais notável daquele, a disciplina das obrigações e dos contratos comerciais. Não há, todavia, o risco de torná-lo direiro comum como o de sucessões e o das coisas.

O trabalho ainda revelou pensamentos contrários e a favor das unificações, ao dizer que nem todos os doutrinadores brasileiros tinham a visão da unificação como promissora. Para estes, o regime jurídico dos contratos aparentemente não pode ser unitário, os contratos apresentam-se mal regulados e o Código deixou de regular fortemenre a questão da desconsideração da personalidade jurídica, os novos contratos, a limitação da responsabilidade do empresátio individual e as sociedades unipessoais, mantendo a possibilidade de existirem modelos fictícios de contratos de sociedades por quotas de responsabilidade limitada apenas para o enquadramento legal, entre outros tópicos.

Mas o ponto crucial foi que o Código tratou dos processos de fusão, incorporação e outras formas de reorganização socictária, mesmo que isso tenha ocorrido em linhas gerais.

Assim, o fenômeno concentracionista se justifica em buscar diminuição de custos, viabilizar novos mercados, benefícios fiscais, racionalizar a produção e a administração do negócio, mais facilinente adotar os progressos tecnológicos e desenvolver cabedais, reotganizar as estruturas, evitar a concorrência e acessar investimentos de grande vulto, desencadear uma transferência de tecnologia, facilidades tributárias, um mais eficiente controle de matérias primas, um mais racionalizado uso de mão-de-obra e divisão de riscos e de lucros entre coligadas, entre uma centena de motivos.

Ocorre que a demanda dos processos nas empresas e a consequüente possibilidade do aumento dos comportamentos lesivos ao direito até justificatia uma reavaliação da legislação existente sobre o fenômeno. Então a disciplina da concorrência, reguladora dos processos, é profundamente aferada com a concentração de empresas.

Após viu-se, atentamente, que o interesse do consumidor justifica a concentração de empresas, fazendo aprovar mesmo condutas anticoncortenciais como a eliminação de un fornecedor. Neste caso, os aros somente serão aprovados se ficar demonstrado que a transação acarreta benefícios para o consumidor maiores do que as evenruais restrições à concorrência. E mais, que para autores europeus o beneficio ao consumidor e a reserva a ele de uma parte do lucro resultante é o ohjetivo final e o critério de aplicação do direito da concorrência. 
Por fim, foram estudadas formas de concentração e desconcentração, que são transformação, fusão, incorporação e cisão, esta se operando por cissiparidade, tendo sido observada a questão da responsabilidade, que é solidária, salvo havendo notificação, entre outras como joint venture, grupos de sociedades e consórcios, bem como suas características específicas, em especial a incorporação e fusão de sociedades já controladas, poís neste caso não há duas maiorias acionárias se contrapondo.

Já durante o estudo das fases a serem cumpridas pelas empresas, que são o protocolo e a justificação, a assinatura do contrato, o estabelecimento do valor do eventual reembolso e o exercício do direito de continuar sócio dos que resultam detentores de menos de uma ação, foi dada atenção especial ao oferecimento do direito de recesso. Ai foi visto que a Lei Lobão foi causadora de inúmeras discórdias, por ter sido confusa, desastrada e malfadada e que à época havia servido ao interesse de uma única companhia de grande porte desejosa de ver incorporada uma controlada sua sem que fosse molestada pelo recesso dos minoritários; e que atualmente somente terá direito de recesso nos casos de incorporação, fusão e participação de grupo de sociedades, o titular de açôes que não sejam facilmente negociáveis no mercado aberto de capitais e o titular das que não sejam emitidas por companhias nas quais mais da metade do total das ações emitidas encontrem-se em circulação no metcado.

Mormente, este trabalho tentou com singeleza homenagear a figura de Teixeira de Freitas, exatamente quando o direito contemporâneo passa a admitir princípios pregados há 150 anos, cuja obra foi levada para a Argentina, com Vélez Sarsfield, jurista que do Esboço dele tomou 1.200 arrigos, bem como para outras plagas.

Também personalidades de renome não mediram elogios a este jurista. Segundo Pontes de Mitanda, Teixeira de Freitas produziu uma obta ampla, erudita e fiel ${ }^{212}$, organizada e de técnica codificadora, que se adotada na época unificaria o direito privado na América Latina. Segundo Cândido Mendes ele era o Cujácio brasileiro ${ }^{233}$. Para Túlio Ascarelli foio fundador do movimento da unificação, precedendo em muitos anos a Vivante ${ }^{214}$. De acordo com Reale, foi homem que produziu um ensinamento genial. Nesse sentido encontram-se mais as manifestações de Haroldo Valladão, René David, Luis Varela e Luis de Gasperi e Dr. Narvaja, que o consideram o Savigny americano ${ }^{215}$.

Assim, neste momento em que os direitos privados brasileiros, em determinados aspectos são unificados, sua obra deve ser exaltada. Teixeira de Freitas não estava adiantado, o mundo é que levou um século para vivenciar sua inteligência privilegiada ${ }^{216}$. Esses adjetivos todos poderiam ser acrescentados ao fato de se tratar de um venerável, majestoso, altivo, sublime e augusto jurista, Augusto Teixeira de Freitas!

\footnotetext{
2:2 Citado em KARAM, M. Op. cir, p. 98.

${ }^{213}$ Citado en KARAM. Idem, p. 99.

2.14 Citado em KARAM. Idem, p. 102.

215 Todos citados em DEL'OLMO, F. de S. Op. cit., F. 243.

${ }^{216}$ Idem, p. 246.
} 


\section{REFERÊNCIAS BIBLIOGRÁFICAS}

ARAUJO, Jair Sidnei Freitas de. Responsabilidade do Comerciante Individual. Santo Ângelo: Monografia de Graduaç̃̃o em Direito (IESA), 2000.50 p.

BORBA, José Edwaldo Tavates. Direito societário. 4. ed. Rio de Janeiro: Freitas Bastos, $1998.488 \mathrm{p}$.

BRANCO, Gerson Luiz Carlos; COSTA e SILVA, Regina Margarida. A vida de Teixeira de Freitas e Elementos Centrais de seu Pensamento. Porto Alegte: Curso de Pós-graduação em Diteito (UFRGS). Trabalho de Mestrado, 1994.

BULGARELLI, Waldirio. Contratos mercantis. 3. ed. São Paulo: Atlas, 1984.637 p. $287 \mathrm{p}$. Fusões, incorporações e cisões de sociedades. 3. ed. São Paulo: Atlas, 1998. . O direito de recesso nas hipóteses de incorpotação, fusão, cisão e participação em grupos de sociedades: exclusão acarretada pela Lei 7.958 de 20.12.89. Revista de Direito Mercantil, industrial, econômico efinanceiro. São Paulo: Revista dos Tribunais, a. 33, v. 95, jul./set. 1994. p. 71-79.

. O direito dos grupos e a concentração de empresas. São Paulo: Universitária de Direito, 1975. $162 \mathrm{p}$.

Tratado de direito empresarial. 2. ed. São Paulo: Atlas, 1995.285 p.

CARVALHO, Patrícia. Joint Venture: um olhar voltado para o futuro. Revista de Direito Privado. São Paulo: Revista dos Tribunais, n. 6, abr./jun. 2001. p. 162-172.

COELHO, Fábio Ulhoa. Curso de direito comercial. 3. ed. São Paulo: Saraiva, 2000. 485 p. v. 1 .

COMPARATO, Fábio Konder. Atualidades. Revista de Direito Mercantil, industrial, econômico efinanceiro. São Paulo: Revista dos Tribunais, a. 14, v. 17, 1975. p. $173-179$.

. O novo direito de retirada do acionista nos casos de fusão e incorporação. Revista de Direito Mercantil, industrial, econômico e financeiro. São Paulo: Malheiros, a. 38, v. 116, out./dez. 1999. p. 11-16.

COUTO e SILVA, Clóvis Veríssimo do. O conceito de empresa no direito brasileiro. Revista dos Tribunais. São Paulo: Revista dos Tribunais, a. 75, v. 613, nov. 1986. p. 21-31.

DEL OLMO, Florisbal de Souza. Augusto Teixeira de Freitas: o protojurista do Mercosul. In: PIMENTEJ, Luiz Otávio (Coord.). Mercosul, Alça e Integração Euro-Latino. Americana. Curitiba: Juruá, 2001. p. 239-247.v. 1.

ÉBOLI, Evandro. Presidente sanciona hoje o novo Código Civil. O Globo. Rio de Janeiro, 10 jan. 2002, p. 11.

EIZIRIK, Nelson. Notas sobre o direito de recesso na incotporação, fusão e cisão das companhias. Revista de Direito Mercantil, industrial, econômico e financeiro. São Paulo: Malheiros, a. 37, v. 113, jan./mar. 1999. p. 124-129. 
Reforma das S.A. e direito de recesso. Revista de Direito Mercantil, industrial, econômico efinanceiro. São Paulo: Malheiros, a. 36, v. 111, jul./set. 1998. p. 74-85.

FARIA, Werter R. Direito da Concorrência e Contrato de Distribuição. Porto Alegre: Sergio Antonio Fabris Editor, 1992. 144 p.

FONSECA, José Júlio Borges da. Disciplina da concortência nas operações de concentração empresarial. Revista de Direito Mercantil, industrial, econômico e financeiro. São Paulo: Revista dos Tribunais, a. 35, v. 102, abr./jun. 1996. p. 26-37.

GAVIRIA GUTIÉRREZ, Enrique. Sociedad unipersonal o empresa unipersonal. Revista de la Facultad de Derecho y Ciencias Políticas. Medellín: Editorial, n. 97, 1996. p. 221243.

GIARETA, Gerci. Teoria da Despersonalização da Pessoa Juńdica. Revista de Direito Civil, n. 48 , abr/jun 1989 . p. 7 a 22.

GOMES, Yaná Christina Eubank. A teoria da desconsideração da personalidade jurídica e a responsabilidade dos sócios, gerentes e administradores de empresas nas sociedades comerciais, em face do Código de Proteção e Defesa do Consumidor. In: UNIVERSIDADE de Cuiabá. Estudos de direito comercial. Cuiabá: Edunic, 1997. p. 89 a 91.

GOMES, Otlando. Introdução ao direito civil. 16. ed. Rio de Janeiro: Forense, 2000. 562 p.

GRAEFF JÚNIOR, Cristiano. Compêndio elementar das sociedades comerciais. Porto Alegre: Livraria do Advogado, 1997. 323 p.

HENTZ, Luiz Antonio Soares. Direito comercial atual: de acordo com a teoria da empresa. 3. ed. São Paulo: Saraiva, 2000.177 p.

Notas sobre a desconsideração da personalidade jurídica: a experiência portuguesa. Revista de Direito Mercantil, industrial, econômico e financeiro. São Paulo: Revista dos Tribunais, a. 35, v. 101, јал./mar. 1996. p. 109-113.

KARAM, Munir. Teixeira de Freitas e o processo de codificação do Direito Civil Brasileiro. Revista de Direito Civil, Imobiliário, Agrário e Empresarial. São Paulo: Revista dos Tribunais, n. 29. p. 95-112,

KERN, Adriana Sívia Klein. Direito da Concorrência no Brasil: evolução normativa e órgãos responsáveis pela sua tutela. Canoas: Monografia de Graduação em Direito (ULBRA), $2001.58 \mathrm{p}$.

LEÃES, Luiz Gastão Paes de Barros. Incorporação de companhia controlada. Revista de Direito Mercantil, industrial, econômico efinanceiro. São Paulo: Revista dos Tribunais, a. 33, v. 94 , abr./jun. 1994. p. $87-96$.

LETE DEL RÍO, José Manuel. Derecho de Obligaciones. 2. ed. Madrid: Tecnos, 1995. v. 3.

LIMA, Osmat Brina Corrêa. A teoria da desconsideração da personalidade jurídica descomplicada. Revista da Faculdade de Direito Milton Campos. Belo Horizonte: Del Rey, n. 6, 1999. p. 225-229.

Incorporação de empresas. Belo Horizonte: Del Rey, 1993. 77 p. 
LOPES, José Reinaldo de Lima. Direito da concorrência e direito do consumidor. Revista de Direito do Consumidor. São Paulo: Revista dos Tribunais, n. 34, abr./jun. 2000. p. 79-87.

LUCCA, Newton de. O direito de recesso no direito brasileiro e na legislação comparada. Revista de Direito Mercantil, industrial, econômico e financeiro. São Paulo: Malheiros, a. 37, v. 114, abr./jun. 1999. p. 7-33.

MAC-DONALD, Norber to da Costa Caruso. O projeto de Código Civil e o Direito Comercial. Revista da Faculdade de Direito da Universidade Federal do Rio Grande do Sul. Porto Alegre: Sintese, v. 16, 1999. p. 139-160.

MADRID PARRA, Agustín. Transformación, fusión y escisión de las sociedades mercantiles. In: JIMÉNEZ SÁNCHEZ, Guillermo J. (Coord.). Derecho mercantil. Barcelona: Ariel. p. $516-528$.

MAGALHÃES, José Carlos de; SAMPAIO, Onofre Carlos de Arruda. A concentração de empresas e a competência do CADE. Revista de Direito Mercantil, industrial, econômico e financeiro. São Paulo: Malheiros, a. 37, v. 113, jan./mar. 1999. p. 30 44.

MARQUES, Cláudia Lima. Cem anos de Código Civil Alemão: o BGB de 1896 e o Código Civil Brasileiro de 1916. Revista da Faculdade de Direito da Universidade Federal do Rio Grande do Sul. Porto Alegre: Síntese, v. 13/14, 1997. p. 71-97.

. Contratos no Código de Defesa do Consumidor: o novo regime das relafóes contratuais. 3. ed. São Paulo: Revista dos Tribunais, 1998. 668 p.

MARTINS, Fran. Contratos e obrigaçôes comerciais, 15. ed. Rio de Janeiro: Forense, 2000. $542 \mathrm{p}$.

. Curso de direito comercial: empresa comercial, empresários individuais, microempresas, sociedades comerciais, fundo de comércio. 24. ed. Rio de Janeiro: Forense, $1999.384 \mathrm{p}$.

MARTINS-COSTA, Judith. O direito privado como um 'sistema em construção'; as cláusulas gerais no Projeto do Código Civil Brasileiro. Revista da Faculdade de Direito da Universidade Federal do Rio Grande do Sul. Potto Alegre: Síntese, v. 15, 1998. p. 129-154.

MELEDO-BRIAND, Danièle. A consideração dos interesses do consumidor e o direito da concorrência. Revista de Direito do Consumidor. São Paulo: Revista dos Tribunais, n. 35 , jul./set. 2000. p. 39-59.

MENDONÇA, José Xavier Carvalho de. Tratado de direito comercial brasileiro. Campinas: Bookseller, 2001.540 p. v. 2, t. 2.

MENEZES, Paulo Lucena de. A disciplina do direito de recesso no Projeto de Reforma da Lei das Sociedades Anônimas. Revista da Faculdade de Direito da Universidade Federal do Rio Grande do Sul. Porto Alegre: Síntese, v. 13/14, 1997. p. 235-244.

MORAES, Amanda Gama. Contratos intetnacionais, joint ventures e tipos de joint ventures. Revista da Faculdade de Direito de Olinda. Olinda: Associação de Ensino Superior de Olinda, n.4, v. 3, 1999. p. 211-233. 
MORITZ, Renata Brandão. As hipóteses de recesso na Lei das Sociedades Anônimas. Revista de Direito Mercantil, industrial, econômico e financeiro. São Paulo: Revista dos Tribunais, a. 35, v. 101, jan./mar. 1996. p. 56-75.

OLIVEIRA, Juarez de; MACHADO, Antônio Cláudio da Costa (Orgs.). Brasil: Novo código civil. São Paulo: Oliveira Mendes, $1998.431 \mathrm{p}$.

PINHO, Luciano Fialho de. A desconsideração da personalidade jurídica e a proteção do consumidor no Código de Defesa do consumidor. Revista da Faculdade de Direito Milton Campos. Belo Horizonte: Del Rey, n. 4, 1997. p. 77-101.

PROENÇA, José Matcelo Martins. Concentração empresarial e o direito da concorrência. São Paulo: Saraiva, $2001.196 \mathrm{p}$.

REALE, Miguel. O projeto do novo código civil situação após a aprovação pelo Senado Federal. 2. ed. São Paulo: Sataiva, 1999.276 p.

Questôes de direito privado. São Paulo: Saraiva, 1997.193 p.

REQUIÃO, Rubens. Curso de direito comercial. 23. ed. São Paulo: Saraiva, 1998. 440 p. v. 1.

ROCHA, João Luiz Coelho da. Os consórcios de empresas e seus riscos jurídicos. Revista de Direito Mercantil, industrial, econômico e financeiro. São Paulo: Malheiros, a. 37, v. 115, jul./set. 1999. p. 83-87.

SALOMÃO FILIHO, Calixto. A sociedade unipessoal. São Paulo: Malheiros, 1995.242 p.

SILVA, Luiz Antonio Guerra da. Contemporaneidade do Código Comercial imperial: breves considerações. Revista de Direito Mercantil, industrial, econômico efinanceiro. São Paulo: Malheiros, a. 37, v. 115, jul./set. 1999. p. 120-123.

SQUASSONI, Christian Max Finardi. O direiro de continuar sócio de S/A face às reorganizações societárias. Revista de Direito Mercantil, industrial, econômico e financeiro. São Paulo: Malheiros, a. 37, v. 114, abr./jun. 1999. p. 140-145.

VAZ, Isabel. Direito econômico da concorrência. Rio de Janeiro: Forense, 1993. 681 p.

. Os interesses do consumidor nas fusões e incorporações de empresas. Revista de Direito do Consumidor. São Paulo: Revista dos Tribunais, a. 9, n. 35, jul./set. 2000. p. 219-231.

VENTURA, Raúl. Fusão, cisão, transformação de sociedades: comentário ao Código das sociedades comerciais. Coimbra: Almedina, $1990.645 \mathrm{p}$.

VIVAN'TE, César. La unidad del Derecho Privado en materia de obligaciones. Madrid: Victoriano Suárez, 1925.105 p.

WALD, Arnoldo. Da responsabilidade solidária na cisão e da notificação às empresas devedoras. Revista de Direito Mercantil, industrial, econômico e financeiro. São Paulo: Malheiros, a. 36, v. 111, jul./set. 1998. p. 52-56. 